NBER WORKING PAPER SERIES

\title{
INTERNATIONAL JOINT VENTURES AND INTERNAL VS. EXTERNAL TECHNOLOGY TRANSFER: EVIDENCE FROM CHINA
}

\author{
Kun Jiang \\ Wolfgang Keller \\ Larry D. Qiu \\ William Ridley \\ Working Paper 24455 \\ http://www.nber.org/papers/w24455
NATIONAL BUREAU OF ECONOMIC RESEARCH
1050 Massachusetts Avenue
Cambridge, MA 02138
March 2018, Revised April 2023

Thanks to the editor for useful comments and guidance, as well as to two referees for comments that have improved this paper. We would also like to thank Chad Bown, Loren Brandt, Lee Branstetter, Beata Javorcik, and Shang-jin Wei, as well as participants at numerous venues for helpful comments and suggestions. Chaoqun Zhan has provided excellent research assistance. This project was financially supported by RGC Competitive Earmarked Research Grant No. 17501914 of the Hong Kong Special Administrative Region Government. The views expressed herein are those of the authors and do not necessarily reflect the views of the National Bureau of Economic Research.

NBER working papers are circulated for discussion and comment purposes. They have not been peer-reviewed or been subject to the review by the NBER Board of Directors that accompanies official NBER publications.

(C) 2018 by Kun Jiang, Wolfgang Keller, Larry D. Qiu, and William Ridley. All rights reserved. Short sections of text, not to exceed two paragraphs, may be quoted without explicit permission provided that full credit, including $(\odot$ notice, is given to the source. 
International Joint Ventures and Internal vs. External Technology Transfer: Evidence from

China

Kun Jiang, Wolfgang Keller, Larry D. Qiu, and William Ridley

NBER Working Paper No. 24455

March 2018, Revised April 2023

JEL No. F23,O31,O34

\begin{abstract}
We study the economics of international joint ventures using administrative data for China. We first show that foreign investors choose Chinese partners that are relatively large, productive, and more innovative to set up their joint venture. Using a difference-in-differences framework and accounting for these selection effects, we then provide evidence that joint ventures lead to domestic benefits in the form of productivity and technological spillovers to both the Chinese partners in joint ventures as well as other domestic Chinese firms. Exploiting the easing of joint venture requirements as China entered the WTO in the year 2001, we further show that spillovers from joint ventures to other domestic firms increased in the wake of China's WTO accession, consistent with gains from foreign technology rising due to enhanced commitment through the rules-based WTO system. Our results shed new light on the efficacy of FDI performance requirements as well as on claims regarding international technology transfer that underpinned the China-US trade war.
\end{abstract}

Kun Jiang

Business School

University of Nottingham

United Kingdom

Kun.Jiang@nottingham.ac.uk

Wolfgang Keller

Department of Economics

University of Colorado, Boulder

Boulder, CO 80309-0256

and NBER

Wolfgang.Keller@colorado.edu
Larry D. Qiu

Department of Economics

Lingnan University

Tuen Mun

Hong Kong

larryqiu@ln.edu.hk

William Ridley

Department of Agricultural

and Consumer Economics

315 Mumford Hall

1301 W Gregory Dr

Urbana, IL 61801

wridley@illinois.edu 


\section{Introduction}

Foreign direct investment (FDI) is a leading explanation for why outward-oriented economies perform better than inward-oriented economies because foreign multinationals bring advanced technological knowledge to firms in the local economy (e.g., Keller, 2022). For many years, host country governments have used performance requirements, such as requiring foreign multinationals to partner with a domestic firm to form a joint venture (JV), to foster technology transfer (UNCTAD, 2003). ${ }^{1}$ Nowhere are such international JVs more prominent than in China, where in the wake of the country's opening to FDI in 1979 a flood of foreign investment entered one of the world's largest economies, with just over 6,000 new international JVs amounting to 27.8 billion USD in investment established in 2015 alone (based on statistics from China's Investment Promotion Agency). As a fundamental component of its accession to the World Trade Organization (WTO) in December 2001, China committed to the worldwide trend of liberalizing its FDI regime by dropping the JV requirement for many investments, though China's FDI policy has remained a frequent point of contention with its trading partners. ${ }^{2}$ However, and despite the central importance of measuring the degree to which international JVs give rise to technological and learning externalities for other domestic firms, we still know surprisingly little about whether such spillovers exist, and if they do, how large they are.

To explore this issue, we investigate the effects of international JVs in China during the period of the country's WTO accession. Our analysis consists of three main elements. First, we empirically characterize the attributes of the domestic Chinese firms selected as partners in the formation of international JVs. Second, and informed by our analysis of partner selection, we implement a difference-in-differences (DID) approach to quantify the extent to which international JVs have been responsible for spillovers reflected in the improved performance of domestic Chinese JV partners in terms of productivity and innovation. We interpret these impacts as "intergenerational" spillovers from the JV to the Chinese partner firm, positive evidence for which is consistent with technology leakage within the boundaries of the JV partnership. ${ }^{3}$ Third and finally, we quantify the existence of industry-level spillovers to other domestic Chinese firms in relation to the prevalence of international JVs within industries - that is, spillovers to firms outside the boundaries of the JV partnership. By also considering the regulatory reforms enacted by the Chinese government during the late 1990s and early 2000s, we exploit the policy change of China's WTO entry to explore whether the structural changes that accompanied the country's WTO accession intensified these industry-level spillovers. Taken together, the three components of our analysis shed light on the

\footnotetext{
${ }^{1}$ Other goals of performance requirements include increasing domestic value added, export generation, and linkage promotion (UNCTAD 2003, Chapter I).

${ }^{2}$ Grievances over China's foreign investment policies were central to the US trade actions that set off the US-China trade war in 2018. US government officials specifically argued that US firms were harmed by China's "forced joint ventures" policy (USTR, 2018).

${ }^{3}$ We refer to these as intergenerational because the JV and the Chinese partner can be seen as child and parent.
} 
important question of whether international JVs facilitate technology transfer and learning effects for domestic firms, questions which were central to US grievances that sparked the US-China trade war.

Employing administrative data from 1998 to 2007 on the universe of Chinese JVs matched to firm-level data, our analysis builds on a unique dataset that combines three sources. There is, first, the universe of JVs together with both the foreign and domestic Chinese partner firms that establish them from the Name List of Foreign and Domestic Joint Ventures in China (Name List for short). ${ }^{4}$ Second, to assess firms' innovation performance we employ the State Intellectual Property Office (SIPO) database, which gives detailed information on all patent applications and grants in China. The two datasets are matched to firm panel data from the National Bureau of Statistics (the Annual Survey of Industrial Firms panel, or ASIF).

Our empirical findings can be summarized as follows. In analyzing the features of Chinese partner firms selected to form international JVs, we find that foreign investors typically choose as partners firms that are relatively productive and innovative in comparison with other firms. Larger firms are also likelier to be selected as partners, as well as those that receive public subsidies. In contrast, government ownership is a deterrent to being chosen to partner in the formation of an international JV. We take care to account for these selection effects in the following analysis of intergenerational spillovers from JVs to domestic JV partner firms.

In assessing whether the establishment of JVs is responsible for gains in the performance of Chinese JV partner firms, and accounting for the fact of non-random partner selection, we find consistent evidence of increases in productivity and innovation for partners in the wake of the JV's formation. This finding, which is novel to the best of our knowledge, is consistent with technology leakage from the JV to the partner firm. We additionally explore whether these results exhibit heterogeneity depending on the origin of the foreign investor in the JV. We find that the largest spillovers on domestic partners' performance typically arise for JVs originating from the United States, Germany, and the United Kingdom, i.e., countries at the leading edge of the global technological frontier.

We also find evidence for strong technological learning outside of the JV. International JVs generate positive externalities in terms of productivity and patenting to Chinese firms that operate in the same industry (i.e., horizontal spillovers). This effect is consistent with technological externalities from JVs to other Chinese firms. Furthermore, firms selling to joint ventures benefit from technological externalities as well (i.e., backward spillovers). We show that these spillovers increased in magnitude following China's WTO accession, a finding which we attribute to the liberalization of China's foreign investment rules causing increased technological learning externalities to Chinese firms. These

\footnotetext{
${ }^{4}$ The joint venture is a new, legally independent firm created through the partnership of the foreign investor and a selected Chinese partner firm.
} 
findings are also consistent with the notion that China's WTO membership reduced uncertainty for foreign investors regarding China's future FDI regulations, thereby heightening the incentives to transfer technology to their Chinese JVs. ${ }^{5}$

This paper makes two main contributions. First, we quantitatively examine the effects of JVs in a major world market. While JV requirements have been employed widely, including in India, Mexico, Turkey, Nigeria, and Malaysia, systematic evidence on the impacts of JVs remains limited. Many of the existing studies on this topic rely on small samples, such as UNCTAD's (2003) impact assessment of India's JV requirements based only on the investment of two Japanese motorcycle companies. While industry and case studies can be useful, such as that of China's automobile industry by Howell (2018), generalizability remains an important issue. By examining all JVs in China based on a comprehensive firm-level dataset, we put this concern to rest. Additionally, and complementing the recent analysis of FDI spillovers by Lu, Tao, and Zhu (2017), our approach advances the literature by identifying JV effects based on a policy change, i.e., the lifting of many JV requirements as China entered the WTO in December of 2001. Consequently, by establishing the existence and size of JV spillovers both internal and external to the boundaries of the JV, our findings are informative for ongoing debates about the extent of technology transfer facilitated by international JVs in China.

Second, our analysis sheds new light on foreign investment in China, an issue of heightened importance because of the size of China's economy. Some of the earliest empirical research on this topic examines productivity spillovers from FDI in China's electronics and textile industries (Hu and Jefferson, 2002). Over time, the literature has evolved to employ longitudinal micro data and multiple economic outcomes, though the evidence on FDI learning effects remains mixed (e.g., Huang, 2004, Wei and Liu, 2006). Our analysis complements Javorcik (2004) and Keller and Yeaple's (2009) work by identifying FDI spillovers through a policy change in a large economy. ${ }^{6}$ Lu, Tao, and Zhu (2017) also examine FDI effects in China using the ASIF firm panel data. Our analysis differs in that we present results on international JVs, on which less is generally known. We go beyond Van Reenen and Yueh's (2012) recent study of joint ventures in China by analyzing horizontal and vertical industry externalities, issues of central relevance to policy questions relating to foreign investment.

The remainder of the paper is organized as follows. In Section 2 we give background on the policy environment for FDI in China and how it changed as China became a member of the WTO. We

\footnotetext{
${ }^{5}$ Such policy uncertainty has recently been emphasized as an important determinant of firm behavior by Handley and Limão (2015) and Pierce and Schott (2016).

${ }^{6}$ Alfaro-Urena, Manelici, and Vasquez (2022) have recently employed actual firm-to-firm data instead of inputoutput tables to model firm linkages; they find even stronger evidence for important vertical linkages. Earlier work in this dimension includes that of Javorcik and Spatareanu (2009), who employ information on whether local firms sell to a foreign multinational for a sample of Czech firms.
} 
also provide a conceptual discussion linking the decisions of foreign investors to transfer technology to their international JVs, with a particular emphasis on the Chinese context. In Section 3, we describe our firm-level dataset and quantify the main factors that determine the choice of local partner from the point of view of foreign investors. Section 4 presents evidence on the impact of JV formation, focusing specifically on spillover effects to both domestic partners in international JVs as well as other domestic Chinese firms outside the JV. This section also explores the heterogeneity and robustness of our results. Section 5 provides a concluding discussion and elucidates the policy implications of our findings.

\section{Foreign Direct Investment and International Joint Ventures in China}

\subsection{Developments since 1979}

As part of a broad effort to enact economic reforms, China started to open to foreign investment in 1979 with the "Law on Sino-Foreign Equity Joint Ventures" (passed in July 1979), with further implementation measures introduced and revised in the 1980s to early 1990s (see Lu, Tao, and Zhu 2017). As seen from Figure 1, however, only by the early 1990s did FDI enter the country in significant volumes. This was the consequence of reforms enacted by Deng Xiaoping following his famed Southern Tour of 1992. This led to the gradual relaxation of rules on FDI, in particular in the context of special economic zones which offered favorable regulatory environments to foreign investment (OECD, 2000). Even though the volume of FDI increased in the early 1990s, especially with the spike around 1993 resulting from the establishment of several new special economic zones to attract foreign investment, foreign investors in China were still subject to relatively strict regulatory requirements. ${ }^{7}$

Similar to other countries (especially emerging economies), China's policy towards inward FDI has employed several types of regulatory instruments. One instrument determines which activities or sectors are open to foreign investors at all. One can think of this as a policy operating at the extensive margin. In particular, in 1995 China's central government published the Catalogue for the Guidance of Foreign Investment Industries, which has been revised multiple times since then. This catalogue classifies activities (i.e., highly disaggregated industries) into one of four types, from least to most restricted (encouraged, neutral, restricted, and prohibited). Restricted activities include, for example, the production of various chemicals and pharmaceuticals, the manufacture of certain electronics and machinery, such as cameras or car engines, and the operation of rail and freight companies. An instrument of FDI policy central to our analysis is the JV requirement: foreign

\footnotetext{
${ }^{7}$ A significant portion of the recorded FDI into China from Hong Kong actually originates from China - a process known as "round-tripping," wherein outward capital flows re-enter the Chinese market via Hong Kong for the purpose of avoiding regulation, high taxes, trade barriers, and other administrative obstacles. Our dataset does not allow us to discern the initial origin of capital that is being repatriated to China; rather, we only observe the foreign origin of the FDI.
} 
Figure 1: Chinese FDI Inflows, 1979-2014

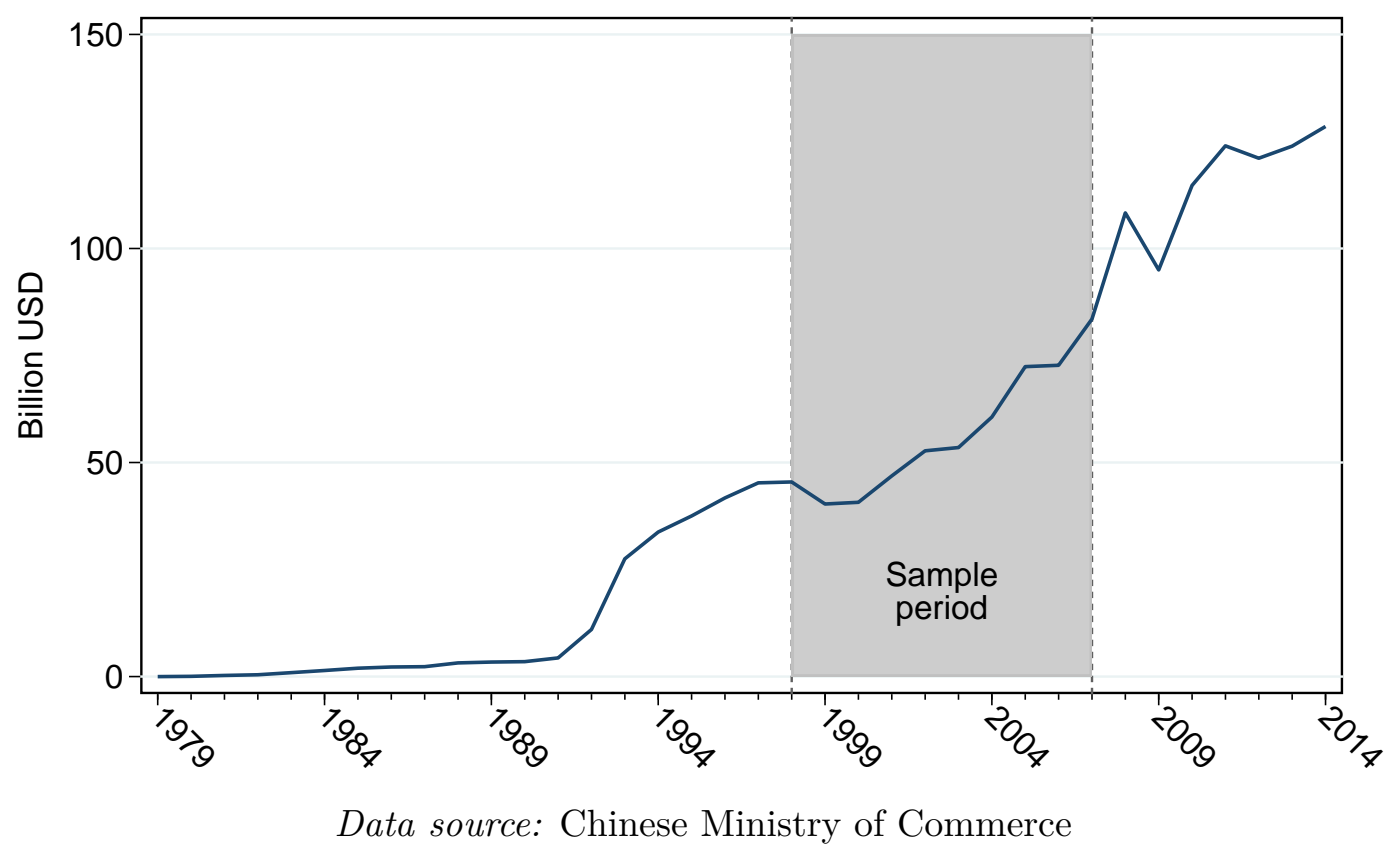

investors operate in China by partnering with a Chinese firm to form a JV, and the transfer of advanced technology and management know-how to Chinese partner firms was typically expected (Lu, Tao, and Zhu, 2017). ${ }^{8}$ Other requirements for FDI in China included domestic content requirements and export requirements. These are some of the main reasons why observers typically described China's level of integration in the world economy by 2001 as shallow (Lardy, 2001).

\subsection{Changes in China's FDI Regime with WTO Entry}

Major changes to China's FDI policy were implemented during China's accession to the World Trade Organization, which culminated China's bid for GATT membership in 1986 and its application for WTO membership in 1995. In addition to tariff reductions and other improvements in market access, as well as the enhanced protection of intellectual property rights (IPRs), WTO membership meant that China would commit to full compliance with the Trade-Related Aspects of Intellectual Property Rights (TRIPS) Agreements and Agreement on Trade-Related Investment Measures (TRIMs), as well as liberalize its FDI policies to adhere to its WTO obligations. Figure 1 shows that after plateauing in the late 1990s, the volume of FDI flows into China experienced a sustained increase to about $\$ 130$ billion per year in 2014 .

In particular, WTO rules explicitly forbid that market access be granted "quid pro quo" in exchange for the transfer of technology. Furthermore, China dropped the JV requirement for a large number of activities. Table A3 in the Appendix provides details on this regulatory liberalization at the

\footnotetext{
${ }^{8}$ Most restricted activities entail a JV requirement, however, there is no one-to-one mapping. Below we will exploit the industry variation of the Catalogue in our analysis.
} 
Table 1: Mode of FDI in China (Realized FDI value in current billion USD)

\begin{tabular}{lrrrr}
\hline & 1997 & 2002 & 2007 & 2012 \\
\hline Equity joint venture & 19.5 & 15.0 & 15.6 & 21.7 \\
\% of total FDI flows & 43.1 & 28.4 & 20.9 & 19.4 \\
Contractual joint venture & 8.9 & 5.1 & 1.4 & 2.3 \\
\% of total FDI flows & 19.7 & 9.6 & 1.9 & 2.1 \\
Wholly foreign-owned enterprise & 16.2 & 31.7 & 57.3 & 86.1 \\
\% of total FDI flows & 35.8 & 60.2 & 76.6 & 77.1 \\
Share company with foreign investment & 0.3 & 0.5 & 0.7 & 1.6 \\
\% of total FDI flows & 0.6 & 0.9 & 0.9 & 1.4 \\
\hline Total FDI & 45.3 & 52.7 & 74.8 & 111.7 \\
\hline Data source: China Statistical Yearbook & & & &
\end{tabular}

two-digit industry level. As Table 1 shows, the share of international JVs in total FDI fell from more than $60 \%$ in 1997 to about $20 \%$ by 2012, while the share of wholly-foreign-owned FDI increased from less than $20 \%$ to about three quarters over the same time period. ${ }^{9}$

Moreover, WTO entry led to changes in FDI policy that were plausibly exogenous because it involved acceding to the commitments of a multilateral agreement with well over one hundred signatory countries. China's importance in global markets and its consequent ability to negotiate specific conditions meant that it was uncertain whether other economic powers such as the European Union and the United States would give their assent to China's WTO membership. ${ }^{10}$ This facet of China's accession also has implications for our estimation approach (described in detail below) relating industry-level spillovers from JVs to the timing of China's WTO membership. Specifically, China's earlier policy reversals with respect to GATT and WTO membership as well as key votes in the United States and the European Union created uncertainty about the ultimate fate of China's application to join the WTO. These considerations arguably limited anticipation effects reflected in firms' behavior and suggest that the policy change of China's WTO accession was plausibly exogenous to individual firms' performance.

\subsection{Joint Ventures and Technology Transfer in China}

A key feature of international JVs in China is the expectation that the foreign investor will contribute capital and technology to the new operation. Such technology transfer has been a

\footnotetext{
${ }^{9}$ Equity joint ventures differ from contractual joint ventures in a number of ways. Unlike equity joint ventures, contractual joint ventures need not be separate legal entities from their parents. Equity joint ventures require a minimum share of foreign ownership to be classified as such, whereas contractual joint ventures require no such provision. In contractual joint ventures, profits are shared between partners on a contractually-agreed upon basis (as opposed to in proportion to each partner's capital contribution). Further, in contractual joint ventures the degree of foreign control embedded in the structure of the joint venture - management, voting, staffing rights, etc. can be negotiated over, and is not necessarily allocated based on equity shares.

${ }^{10}$ There are areas in which China did not fully implement its WTO commitments, such as IPRs and industrial policy (USTR, 2017). At the same time, allegations are made regularly that countries are in violation of WTO rules, and the resolution of such violations is the very purpose of the WTO's dispute settlement mechanism.
} 
prominent aspect of JVs since foreign investment began to enter the Chinese market in earnest. Volkswagen, which in 1985 formed the first international JV in China's automobile sector, in 1991 established another JV with Chinese partner First Auto Works to produce the Audi 100 and Jetta. Notably, this meant that Volkswagen provided its own proprietary design technology to the newly formed JV (Farhooman et al., 2005). Another example from the automobile sector saw General Motors bring its intellectual property to the Chinese market, transferring the designs for Cadillacs, Buick Regal sedans, and Buick GL8 wagons to the JV established by the company in 1994 (Tao and Ho, 2005).

China's Huawei, one of the country's major providers of telecommunication equipment, offers a particularly noteworthy example of technology transfer facilitated via the establishment of JVs. In 2003, Huawei and 3Com, a then-leader in internet protocol (IP) service platforms and access infrastructure for network services, formed the international JV Huawei-3Com. Importantly, the new JV was authorized to use 3Com's relevant IP license. In 2004, Huawei and Siemens AG signed a contract to form a JV for the third-generation mobile standard known as TD-SCDMA. Siemens, one of the main forces behind the development of TD-SCDMA technology, had by 2003 invested $\$ 170$ million in the technology. The new JV benefited significantly from Siemens' investment in the technology. Yet another JV, Huawei Symantec Technologies, was formed in 2007 by Huawei and Symantec to distribute security and storage software products. As the world's then largest developer of security software, Symantec agreed to contribute its security software licenses to the JV. However, the JV was dissolved in 2012, largely owing to Symantec's worries that its connections with Huawei would put the company in a disadvantageous position with the US government.

Conceptually, China's accession to the WTO dramatically altered the incentives faced by foreign investors relating to how much proprietary knowledge to transmit to their Chinese JV partners. In light of the transfer of knowledge typically entailed in JV arrangements as described above, these incentives relate to how foreign investors weigh expectations about the extent to which their technological contributions, either in terms of designs, production processes, management strategies, or other know-how, will promote the success of the JV. At the same time, the knowledge transferred to the JV by the foreign investor will invariably spill over to other firms in some measure, either formally through channels such as joint patenting by the foreign investor and the local partner or less formally via channels such as social gatherings, labor turnover, intermediate input sourcing, or outright theft of intellectual property. Such spillovers could dilute the technological advantage of the foreign investor firm and confer valuable information about products and processes to local competitors, thereby diminishing the incentives to transfer technological knowledge to the JV.

On one hand, the relaxation of JV requirements in specific industries, i.e., allowing foreign investors to establish wholly foreign-owned enterprises (WFOEs) in many sectors for which this was previously forbidden, expanded investors' ability to adopt non-JV investment modes. On the other hand, 
China's adoption of WTO rules on foreign investment and the protection of IPRs, along with the abandonment of quid pro quo market access policies, conceivably heightened investors' incentives to transfer technology to Chinese partners due to the reduced risk of appropriation and theft of knowledge assets. In the analysis that follows we build on the (often anecdotal) understanding of the role of international JVs in facilitating technology transfer by investigating the existence of performance gains for Chinese firms both within and outside the boundaries of the JVs. Moreoever, given the changes in China's foreign investment environment during our period of analysis, we also exploit the timing of China's WTO accession to investigate whether any such spillovers underwent meaningful changes in the post-2001 period.

\section{Data and Determinants of JV Partner Selection}

In this section, we begin by describing the construction and features of our firm-level panel dataset. This dataset is compiled from three sources, which respectively include (i) the ASIF microdata, which records a host of firm-level characteristics for Chinese firms, (ii) comprehensive information on the legal status of Chinese firms with respect to their status as partners in an international JV, (ii) information on firms' patent applications submitted to China's State Intellectual Property Office (SIPO). We then use this data to investigate the characteristics of the Chinese firms selected to serve as partners in international JVs, an exercise that informs our analysis of JV spillovers in the section that follows.

\subsection{Data and Sample}

Our dataset is constructed using three main sources. Our analysis focuses on manufacturing firms in the ASIF dataset for 1998 to 2007, maintained by China's National Bureau of Statistics (NBS). The ASIF panel covers all state-owned and non-state-owned enterprises with annual sales of at least 5 million RMB and provides financial data and other firm-specific information, including for each company its name, address, industry, age, and ownership structure. Brandt, Van Biesebroeck, and Zhang (2014) show that the coverage of ASIF is identical to the corresponding information in the Chinese Statistical Yearbook. The list of newly established international JVs and the corresponding domestic parent firms, together with the foreign firms that are partner to the joint ventures, draws on the Name List of Foreign and Domestic Joint Ventures in China (Name List Database, for short). The Name List Database is released by China's Ministry of Commerce. It contains a multitude of details on each joint venture, such as its name, address, industry code, year of establishment, contracted operation duration, and importantly, the name of the Chinese partner firm that established the joint venture. For the domestic partner firms, the Name List Database provides each firm's industry code and physical address in addition to the name of the firm. We also use information on the patent applications associated with each firm, data which are obtained from China's SIPO patent database. The SIPO database provides complete information 
on all patent applications and grants in China, including the application and publication number of the patent, application and grant year, classification number, type of patent, and assignee of the patent.

These three databases are merged at the level of the firm-year observation to form the sample for our empirical analysis. The match quality is important for our empirical findings. Fortunately, Chinese law requires that a firm have a unique identifier, and this identifier must contain four elements in the order of administrative region (above county level), the firm's name, its industrial sector, and a legal entity identifier; for instance, a particular firm's identifier might be Chongqing (administrative region) Changan (name) Automobile (industrial sector) Co., Ltd. (legal entity identifier). Firms in the same industrial sector cannot use the same name. Moreover, firms have an exclusive right to their names on a regional basis. Therefore, if the firm's name, location, and industry code are entered the same in both the ASIF and Name List databases, this information identifies the same entity. Because of this, we use company name, location, and industry code to identify both the joint venture firms and the domestic international JV partner firms in the ASIF database and the Name List Database year by year. Then, we match the ASIF and SIPO data to incorporate information on each firm's patenting activities.

We follow the strategies from the NBER Patent Data Project in our matching approach. Specifically, we use firm name, location (at the municipal level), and the 2-digit Chinese Industrial Classification (CIC) industry code to merge the datasets with each other. Our empirical results are based on international JVs in China's manufacturing industries observed between 1998 and 2007. Our study covers all domestic partner firms with annual sales of at least 5 million RMB in operation at any point between 1998 and 2007 and the analysis relies on the representativeness of the ASIF database. To assess this we have compared the data in the ASIF data for 2004 to the 2004 Chinese Economic Census (the earliest year in which the Economic Census was conducted), which covers all firms in China. Based on the Census, the total sales in 2004 for all industrial firms totaled 218 billion RMB, whereas the sales for all industrial firms in the ASIF data totaled 196 billion RMB. The enterprises covered by the ASIF thus account for almost all (more than 91\%) of the total sales of all industrial firms in China in 2004. This evidence is consistent with results in Brandt, Van Biesebroeck, and Zhang (2014) and ensures the representativeness of our sample. Appendix Table A2 shows the breakdown by two-digit CIC industries for the firms in the ASIF database as well as domestic international JV partner firms. ${ }^{11}$

The distribution of joint ventures across industries over the sample period is shown in Table 2. Joint ventures are more likely to be formed in labor-intensive manufacturing industries such as textiles

\footnotetext{
${ }^{11}$ The ASIF data reports firms' industries by CIC Rev. 1994 code from 1998 to 2002, and CIC Rev. 2002 for observations from 2003 to 2007. CIC is itself based on the International Standard Industrial Classification of All Economic Activities (ISIC) industrial classification.
} 
Figure 2: Share of Domestic Firms that are Joint Venture Partners by Province, 2002

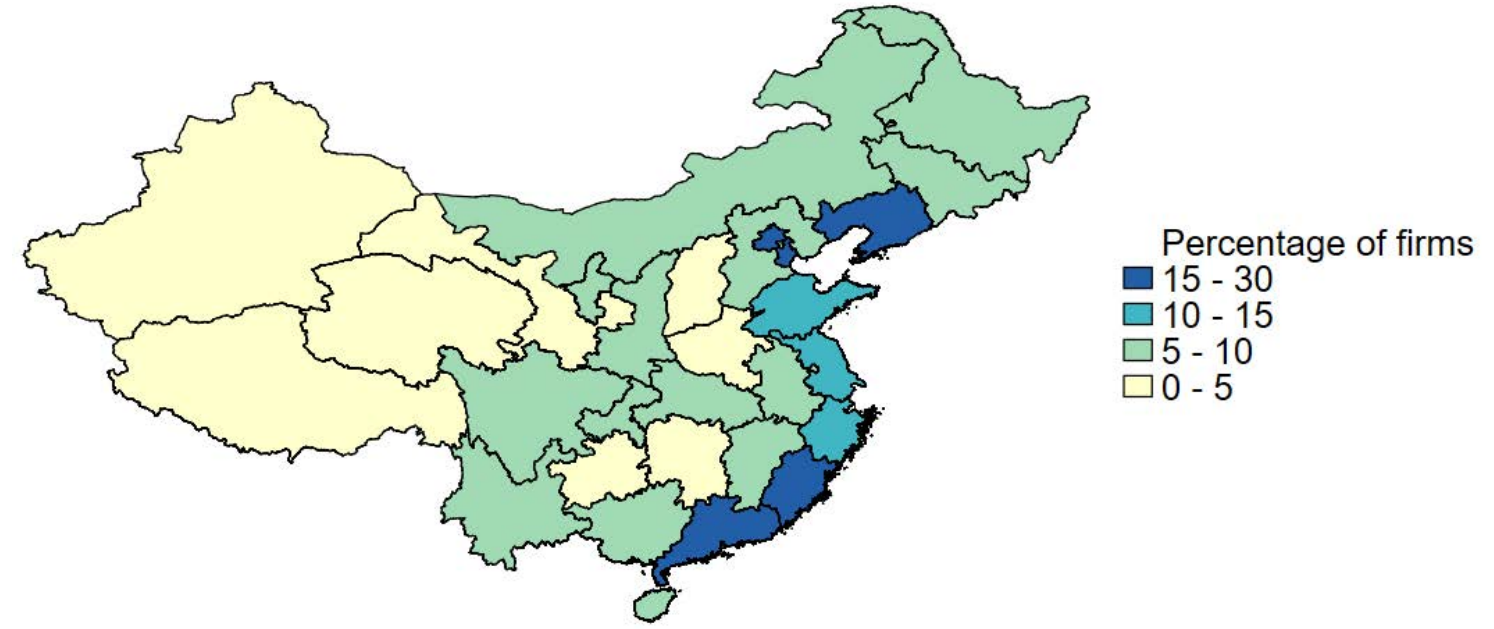

and apparel (CIC 17 and 18) or high-tech industries such as electrical, electronic, and computer equipment manufacturing (CIC 39 and 40), with relatively fewer international JVs formed in industries such as petroleum and metal processing (owing to activities in these industries frequently being classified by Chinese authorities as prohibited or restricted).

We eventually consider as part of our analysis the intersectoral linkages through which industrylevel spillovers might propagate. We measure these linkages using input-output tables for China's manufacturing sectors. As our sample spans the years 1998 to 2007, for each observation year we employ the most contemporary version of the input-output table produced by China's National Bureau of Statistics, with revisions of these input-output tables existing for the years 1997, 2002, 2005, and 2007 (from China's Department of National Economic Accounts (DNEA) 1999, 2005, 2007, and 2009).

The firms involved in the formation of international JVs also vary in where they tend to be located. Figure 2 shows the geographical distribution of the partner firms at the provincial level. Immediately apparent is that international JV partner firms tend to be more common in highly developed coastal areas such as Guangdong, Jiangsu, Zhejiang, Shanghai and Shandong, with comparatively fewer partner firms located in the western, central, and northern areas of the country. To account for the regional component of international JV formation, we control for geographical characteristics in our empirical analysis. ${ }^{12}$

\subsection{Variable Definitions}

We focus on several firm attributes in our analysis, some of which are directly available in the data and some that we estimate. First, we consider revenue total factor productivity (TFP-R).

\footnotetext{
${ }^{12}$ Further detail on the distribution of international JVs by Chinese province is given in Appendix Table A1.
} 


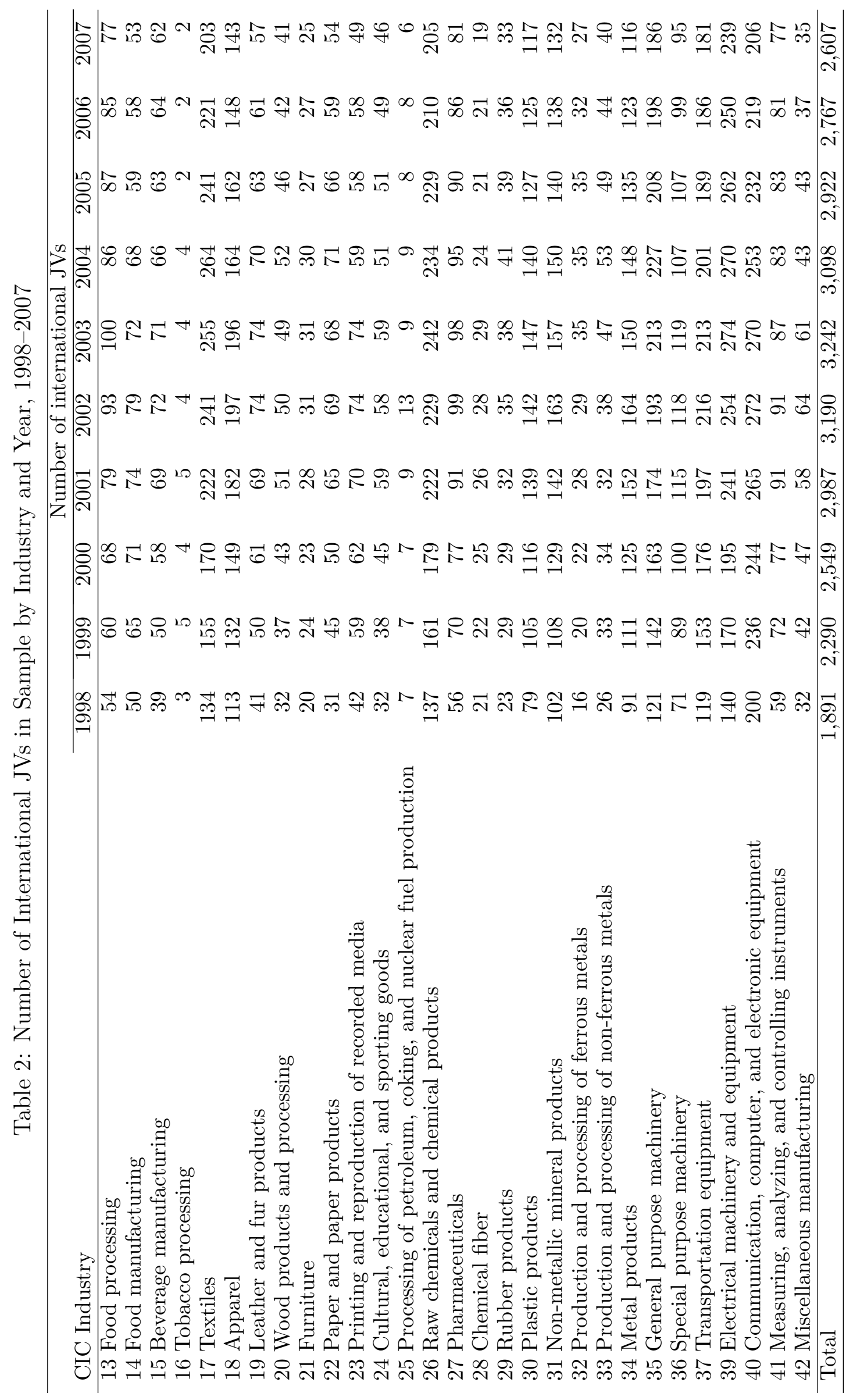


Given that we do not have information on physical productivity, a generic problem is that changing markups as well as the accuracy and timing of the application of price indices may affect our productivity results. We measure total factor productivity following the methodology of Olley and Pakes (1996). ${ }^{13}$ This methods is well-established in the productivity literature, as it addresses simultaneity caused by unobserved productivity shocks and non-random sample selection induced by different exit probabilities. Appendix A gives an overview of these methods, with more description of our TFP estimates provided in Jiang, Keller, Qiu, and Ridley (2019).

Next, we focus on both technological output and commercialized output. Patents is the count of patent applications of all types submitted at China's national patent office in a particular year, which is used to measure total technological output. We typically employ Patents in logarithmic form, and because of the lag time between R\&D and patenting, we use the one-year lead on patents. Since the logarithmic form will remove firms with zero patenting from the sample, we will also estimate our patent regressions by employing an inverse hyperbolic sine (IHS) transformation, and find that it leads to similar results. The patent data are from SIPO, which compiles complete information for all patents filed in China since 1996. New Product Ratio is a firm's share of sales from new products of its total sales in a given year. Finally, to measure export activity, Export Ratio is the ratio of a firm's export volume in a given year over its total sales.

We also want to capture the domestic partners' ownership structures and their connections to the government. To account for these factors, we measure Foreign Share as the ratio of equity owned by foreigners over total equity. Similarly, Govt. Share measures the ratio of government-owned equity over total equity. In addition, we use Subsidy, a dummy variable equal to one if the domestic firm receives any subsidies from the government in a given year and zero otherwise, to account for a domestic firm's political connections. Two additional firm controls are included in our empirics, including Size (the total number of employees of the firm) and Age (the number of years a firm has been in operation). To ensure that results are not driven by entry and exit into the sample, we focus on firms that have at least five observations during our sample period. All of the variables are winsorized at the 1 st and 99th percentiles to eliminate the influence of outliers.

The summary statistics for the above variables are presented in Table 3 for our full sample of Chinese firms and domestic international JV partners. ${ }^{14}$ It is apparent that there appear to be underlying pre-existing differences between the Chinese firms selected as JV partners and those that are not. Domestic international JV partners are on average older, larger, have smaller government ownership stakes, are more export-oriented, and patent more than non-international JV partners;

\footnotetext{
${ }^{13}$ We have also explored alternative estimates of firms' TFP obtained using the methodology of Wooldridge (2009). Our findings based on this alternative approach to measuring productivity are qualitatively identical to our baseline results.

${ }^{14}$ We exclude JV firms themselves from the sample, though we do explore whether JV firms themselves perform better than other domestic Chinese firms in Appendix B.
} 
Table 3: Sample Summary Statistics

\begin{tabular}{lccr}
\hline \multicolumn{1}{l}{ Variable } & Obs. & Mean & \multicolumn{1}{c}{ Std. dev. } \\
\hline \multicolumn{1}{l}{ Non-International-JV-Partner Firms $\mathbf{( 1 1 5 , 7 1 1}$} & firms) \\
Age & 773,217 & 11.27 & 7.97 \\
Employees & 773,217 & 289.91 & 814.33 \\
Foreign Share & 773,217 & 0.01 & 0.07 \\
Govt. Share & 773,217 & 0.16 & 0.35 \\
Export Ratio & 773,217 & 0.10 & 0.26 \\
TFP & 773,217 & 9.00 & 1.54 \\
Patents & 773,217 & 0.12 & 5.44 \\
Sales & 773,217 & $69,985.18$ & $562,154.55$ \\
& & \\
International JV Partner Firms & $\mathbf{( 1 7 , 8 7 5}$ firms) & \\
Age & 137,533 & 10.91 & 6.54 \\
Employees & 137,533 & 589.32 & $2,504.87$ \\
Foreign Share & 137,533 & 0.19 & 0.32 \\
Govt. Share & 137,533 & 0.1 & 0.26 \\
Export Ratio & 137,533 & 0.3 & 0.41 \\
TFP & 137,533 & 9.65 & 1.54 \\
Patents & 137,533 & 0.43 & 17.1 \\
Sales & 137,533 & $193,940.84$ & $1,382,640.29$ \\
\hline
\end{tabular}

we will control for these underlying differences in firm attributes when estimating the determinants of selection as well as the within-firm effects of international JV formation.

We further examine the average characteristics of the industries in our sample over time with respect to the prevalence of international JVs in Table 4. Horizontal gives the share of industry sales respectively accounted for by international JVs. Backward is a share-weighted average of the Horizontal measure in industries downstream from industry $j$ (with the weights measuring the importance of destination industry $k \neq j$ as a recipient of intermediate inputs from $j$ ), while Forward is defined analogously to Backward but as a measure of JV penetration in industries upstream from $j$ (these measures are discussed in more detail in Section 4.3). The average share of industry sales accounted for by joint ventures declined from 5.0 to 3.1 percent of average industry sales. Parallel to the results on horizontal JV penetration, the exposure of Chinese firms to international JVs in industries besides their own, as measured by the Backward and Forward measures, has evolved in a similar fashion.

Table 4: Industry Spillover Variables, Average by Year

\begin{tabular}{lccc}
\hline & 1998 & 2002 & 2007 \\
\hline Horizontal & 4.4 & 5.0 & 3.1 \\
Backward & 4.0 & 4.7 & 2.9 \\
Forward & 3.1 & 3.8 & 2.2 \\
\hline
\end{tabular}




\subsection{The Choice of Joint Venture Partners}

To analyze foreign firms' joint venture partner choice in China, we specify a simple limited dependent variable model describing the selection of some firm $i$ as an international JV partner as a function of the firm's characteristics in year $t$ :

$$
P T_{\_} \text {Select }_{i t}=f\left(\boldsymbol{X}_{i t}^{\prime} \gamma, \eta_{j}, \nu_{r}, \mu_{t}, \varepsilon_{i t}\right)
$$

where $j$ and $r$, respectively, index an observation's two-digit industry and the province in which the firm is headquartered. The dependent variable $P T \_$Select $_{i t}$ is equal to one if Chinese firm $i$ is selected as an international JV partner in year $t$, and zero otherwise. $\boldsymbol{X}_{i t}$ is a vector of firm-level attributes that might affect selection, such as the firm's productivity, while $\eta_{j}, \nu_{r}$, and $\mu_{t}$ represent unobserved characteristics specific to, respectively, the firm's industry, the region in which it operates, and the observation year. Finally, $\varepsilon_{i t}$ is a mean-zero error term. To the extent that firms with certain characteristics are significantly more (or less) likely to be selected, the choice of JV partners is non-random. Furthermore, foreign investors will internalize the characteristics of their Chinese partner firm in their optimal investment strategy.

Shown in Table 5 are results from logistic regressions of equation (1). ${ }^{15}$ The sample in this estimation is comprised of domestic non-JV Chinese firms, excluding firms that are majority foreign-owned. We include various covariates one by one in order to isolate the influence of each.

Larger firms are more likely to be chosen as international JV partners (column 1), as are younger firms (column 2). Selection as a partner in an international JV is more likely for Chinese firms that are partly foreign-owned, while government ownership (i.e., state-owned enterprises) enters with a negative coefficient (column 3). Firms that are subsidized are more likely to be chosen to be a JV partner (column 4), as are firms that sell a large fraction of their output abroad (column 5). Foreigners interested in Chinese JV partners prefer profitable firms (column 6, with profits measured in million RMB), though this effect becomes insignificant (and even negative) with the inclusion of other controls. We also see that, conditional on size, industry, and profitability, more productive firms are significantly more likely to be picked as partners (column 7).

In our later analysis in Section 4.1 we investigate the extent to which domestic firms show improvements in productivity and innovation upon entering into an international JV partnership. If the performance of such firms is typically trending upward before the partnership is even established, we might erroneously assign any observed improvements in partner firms' outcomes as the effects of the JV partnership when they are in reality driven by these pre-existing trends. Column 8 explores this by including the growth rate in firms' TFP between the observation year and two years prior

\footnotetext{
${ }^{15}$ Employing probit regressions, we find broadly similar results.
} 


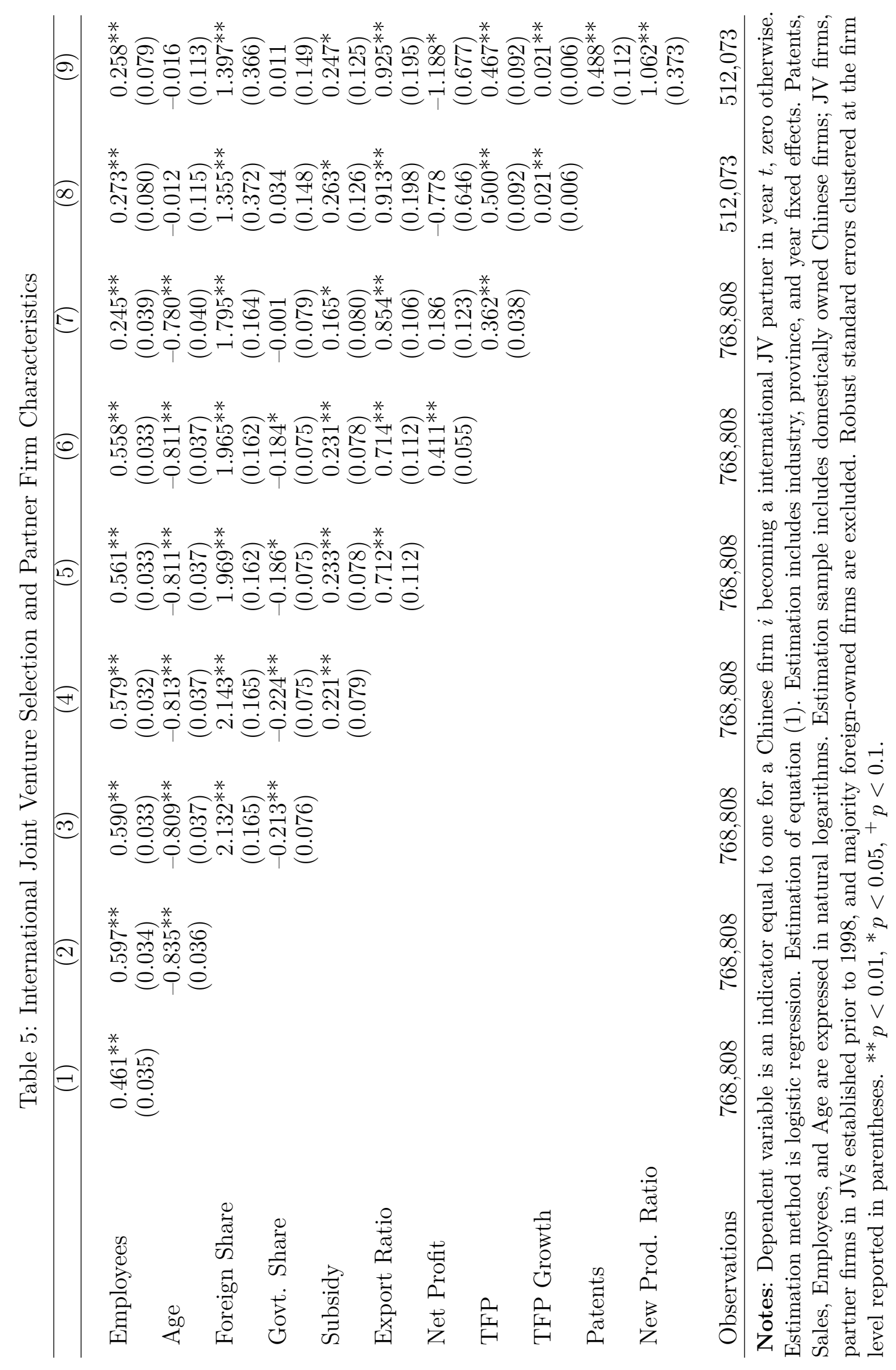


(thus reducing the sample size on account of needing a two-period lag to calculate the growth rate of TFP), and indeed, firms with more pronounced upward trajectories in terms of productivity are more likely to be selected to form a JV partnership. We thus account for these pre-trends in our later analysis.

We are also interested in the role of innovation for international JV partner choice in China; see column 9 of Table 5. The first measure of innovation is the sum of all invention, design, and utility model patent applications, cumulative over the three years preceding (and inclusive of) the observation year; we see that a higher level of recent patenting activity raises the chance that a Chinese firm is picked as a joint venture partner. Furthermore, we examine whether product innovation matters for partner choice. The results show that firms with a relatively high ratio of new products in their total sales are more likely to become partners in international JVs. The new product ratio and patent measures capture different aspects of the innovation activity of these firms, and both are associated with a higher probability of partner choice. ${ }^{16}$

\section{The Impact of Joint Ventures in China}

We next explore the impact of international JVs on China's economy, and in particular, the impact of JVs on other Chinese firms. We first focus on identifying the causal effect of JV formation on the productivity and innovation of Chinese domestic partner firms in the JV. Because any such impacts do not accrue to either the foreign investor or the JV itself, we interpret these effects (if any) as intergenerational externalities that affect the performance of partner firms. We then provide evidence on industry spillovers to domestic Chinese firms outside the JV generated by the presence of international JVs, impacts that manifest on top of those that accrue to partner firms. We begin by introducing our empirical approach and discussing key threats to identification.

\subsection{Estimation Approach}

To estimate the causal effect of JV formation on the Chinese partner firms we employ a DID approach that compares Chinese partner firms to non-partner firms before and after the international $\mathrm{JV}$ is formed. We express the firm-level outcome $y_{i t}$ according to the relationship

$$
y_{i t}=\alpha+\beta_{1}\left[P T_{i} \times J V_{i t}\right]+\boldsymbol{X}_{i t}^{\prime} \gamma+\lambda_{i}+\mu_{t}+\varepsilon_{i t}
$$

where $P T_{i}$ is an indicator variable equal to one if firm $i$ is ever partner to an international JV during the sample period (i.e., part of the "treatment" group of JV partner firms), and zero otherwise. $J V_{i t}$ is a time-varying JV partnership status variable equal to one if firm $i$ in year $t$ is a partner in an international JV, and zero otherwise. $\lambda_{i}$ and $\mu_{t}$ are firm and year fixed effects, respectively. The

\footnotetext{
${ }^{16}$ We have also explored whether the determinants of international JV partner choice changed following China's entry into the WTO, finding no strong evidence for it.
} 
term $\boldsymbol{X}_{i t}$ is a vector of time-varying firm controls including firm size (in terms of employment), age, and markup. Conditional on covariates, we assume that the regression error $\varepsilon_{i t}$ is mean zero and we allow for arbitrary serial correlation patterns by clustering our standard errors at the firm level. The control group in this analysis is the sample of domestic Chinese firms (excluding all JVs and majority foreign-owned firms) that are not JV partners during the sample period. In estimating equation (2), we omit all observations for JV partner firms for which the JV was established prior to the beginning of our sample period, (i.e., "always-treated" units), the inclusion of which has been highlighted by Goodman-Bacon (2021) and others as a source of potential bias in DID estimations.

Of key interest in equation (2) is $\beta_{1}$, estimates of which under certain conditions capture the average impact of JV formation (i.e., $P T_{i} \times J V_{i t}$ ) on firm outcome $y_{i t}$. A key identification condition is that in the absence of treatment, treatment and control observations would have followed identical trends. While this cannot be tested after treatment (since it involves a counterfactual), a common approach is to examine whether there are observable differences in the trends of the outcomes for treated versus control units prior to treatment. To explore these potential pre-trend differences, we implement an event-study approach by estimating

$$
y_{i t}=\alpha+\sum_{\tau=-7}^{7} \beta_{\tau} 1\left\{t-P T Y_{i}=\tau\right\}+\boldsymbol{X}_{i t}^{\prime} \gamma+\lambda_{i}+\mu_{t}+\varepsilon_{i t}
$$

where $P T Y_{i}$ is the year in which firm $i$ becomes a partner in an international $\mathrm{JV}, \tau$ is year relative to treatment (i.e., JV formation) and $1\{\cdot\}$ is an indicator function. The event-study equation (3) is a generalization of equation (2) that estimates one coefficient for each year relative to treatment, including both before and after treatment, rather than a single coefficient capturing a single average post-treatment effect. We estimate equation (3) by considering distinct effects for the seven years before and after the formation of the JV. We exclude the year of JV formation $(\tau=0)$ as the baseline category and accumulate impacts in periods beyond the seven indicated leads and lags into the final lead and lag terms. ${ }^{17}$ Because JVs are established across all of the years in the sample (i.e., because treatment is staggered), we will also consider estimation methods that accommodate such differential treatment timing and other heterogeneous effects.

Figure 3 shows the results of estimating equation (3) with TFP as the left-hand side variable. The main finding of Figure 3 is the absence of systematic differential pre-trends. Specifically, we see wide variation in the relative TFP effects in the years before treatment, with a roughly equal number of positive versus negative point estimates, none of which are significantly different from zero.

The analogous results for patenting are shown in Figure 4. As with our results on productivity,

\footnotetext{
${ }^{17}$ We find broadly similar results in considering different numbers of leads and lags in the estimation of equation (3).
} 
Figure 3: Firm Productivity and International Joint Venture Formation

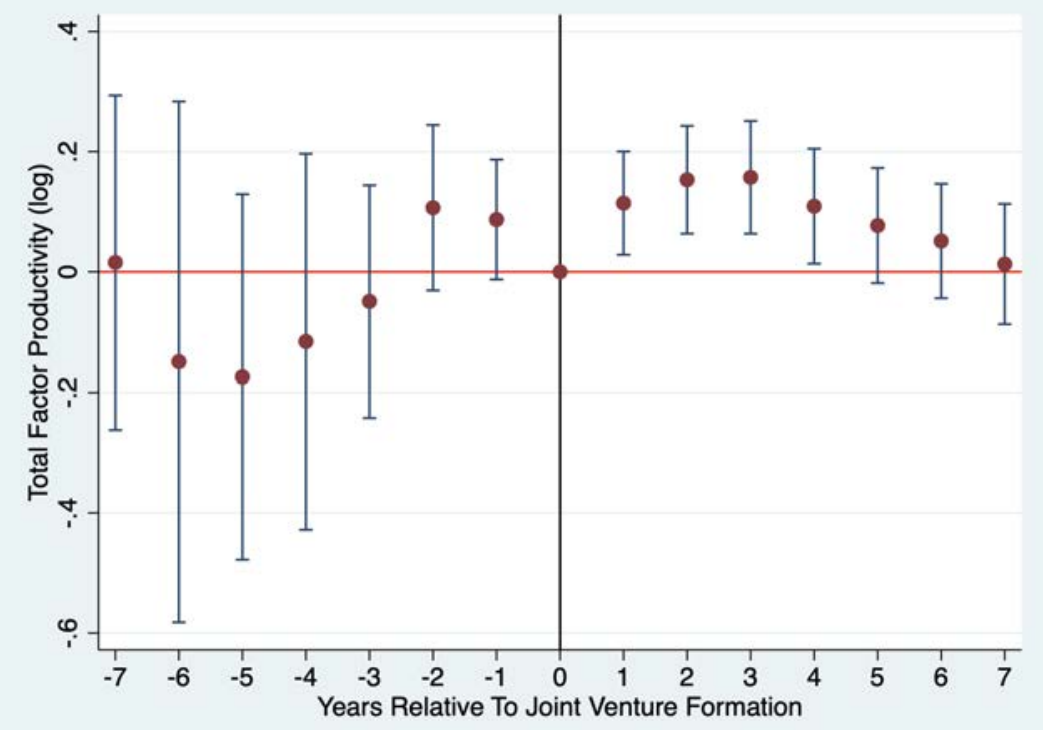

Notes: Figure shows OLS estimates of $\beta_{\tau}$ (equation (3)) with log TFP as the dependent variable; treatment is full years of being Chinese partner to an international JV. Estimation includes firm and year fixed effects, as well as firm controls including employees, age, foreign ownership share, government ownership share, an indicator for subsidization, and firm markups. Sample includes firms with at least five observations and JVs formed 1999 or later, excluding JV firms; Number of observations is 818,$232 ; 99 \%$ confidence intervals shown based on standard errors clustered at the firm level.

we find no evidence for differential trends between treated and control firms in the pre-treatment period. Overall, this absence of differential pre-trends provides evidence that our estimation approach yields the average causal effect of JV formation on Chinese partner firms.

Moreover, the pattern of the post-treatment coefficients in both the TFP and patenting figures suggest a positive impact from JV formation, with the strongest single-year effects on productivity arising somewhat earlier than for patenting. The following analysis examines this further by estimating average treatment effects using the DID estimation equation (2).

\subsection{JV Spillovers on Partner Firms}

Table 6 presents the estimates of the DID specification given by equation (2). As seen in column 1, we estimate that JV formation is associated on average with a $7.3 \%$ increase in firms' TFP. This is consistent with the event-study results of Figure 3. Furthermore, as shown in column 2, JV formation also increases the number of patent applications by firms. We also employ an inverse hyperbolic sine (IHS) ${ }^{18}$ transformation instead of using the $\log ($ patents +1 ) transformation in order to account for zeros in the patent data, which yields a similar estimate on JV formation as is shown in column 3. In sum, we find strong evidence for the existence of positive intergenerational

\footnotetext{
${ }^{18}$ The IHS transformation of a variable $y$ is defined as $\operatorname{arcsinh}(y)=\log \left(y+\sqrt{y^{2}+1}\right)$. This approach has been widely employed to circumvent the issue of log-transforming variables that contain zero values.
} 
Figure 4: Patenting and International Joint Venture Formation

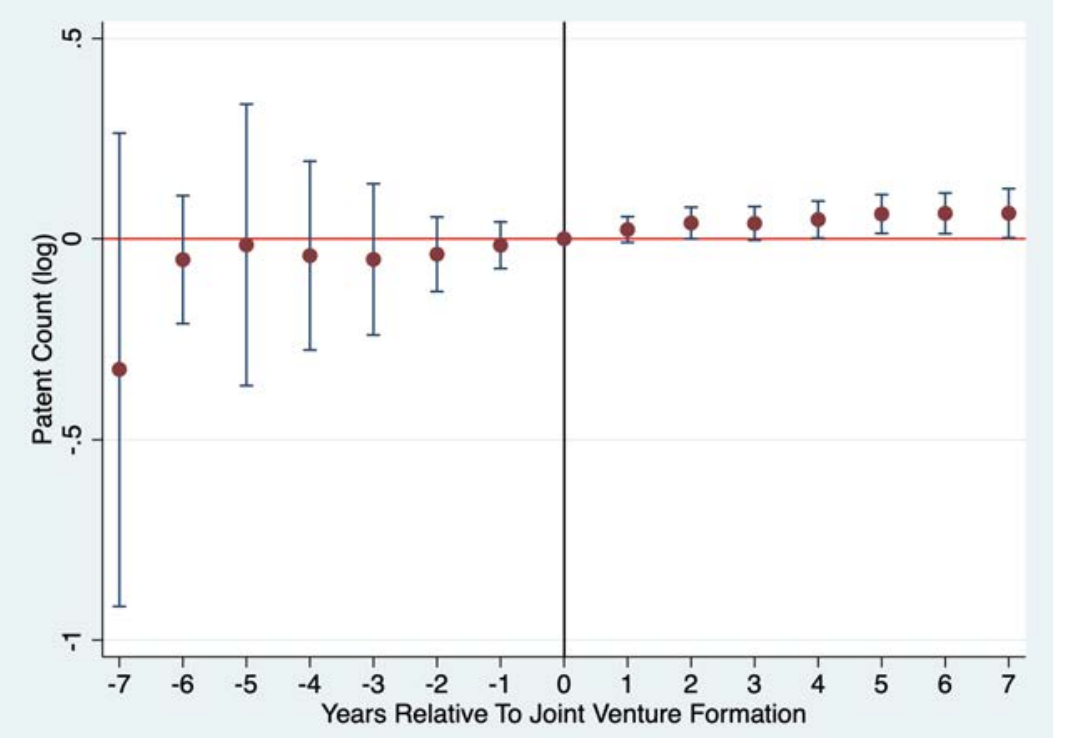

Notes: Figure shows OLS estimates of $\beta_{\tau}$ (equation (3)) with log patent count (plus one) as the dependent variable; treatment is full years of being Chinese partner to an international JV. Specification includes firm and year fixed effects as well as other firm-level controls including log number of employees, log firm age, foreign ownership share, government ownership share, an indicator for government subsidies, and firm markup. Sample includes firms with at least five observations and JVs formed 1999 or later, excluding JV firms; Number of observations is 704,565; $99 \%$ confidence intervals shown based on standard errors clustered at the firm level.

spillovers: Chinese firms that establish partnerships with foreign investors to form a JV experience average increases in innovation and productivity in the order of 5 to $7 \%$

Next, to explore the robustness of our results and investigate sources of heterogeneity, we further examine these benchmark results along a number of different dimensions. The results of these analyses are presented in Table 7 . We first report results from a DID estimator based on that of Borusyak, Jaravel, and Spiess (2021), an approach robust to heterogeneous treatment effects, including those arising from a staggered treatment. While the estimate on patenting impacts remains around $5 \%$ as before, we estimate the productivity effect to be significantly larger at $15 \%$ (as illustrated by the results in columns 1 and 2, respectively). Consequently, we conclude that our baseline OLS results do not overestimate the size of JV spillovers to partner firms because they abstract from heterogeneous effects.

The remaining specifications in Table 7 report a number of additional results for TFP that shed light on the role of several other factors in influencing our results. First, we show that obtaining robust standard errors by bootstrapping, rather than clustering at the firm level, does not change our inference (column 3). Next, we explore the role played by our estimation sample. In our baseline estimation we employ data on all firms that are observed in the sample for at least five years. The use of either a more or less conservative sample restriction does not change the estimated 
Table 6: The Impact of Joint Venture Formation on Partner Firms

\begin{tabular}{|c|c|c|c|}
\hline & $\begin{array}{c}(1) \\
\mathrm{TFP}\end{array}$ & $\begin{array}{l}\text { (2) } \\
\text { Patents }\end{array}$ & $\begin{array}{c}(3) \\
\text { Patents } \\
(\mathrm{IHS})\end{array}$ \\
\hline JV Formation & $\begin{array}{c}0.073^{*} \\
(0.033)\end{array}$ & $\begin{array}{c}0.057^{* *} \\
(0.018)\end{array}$ & $\begin{array}{c}0.069^{* *} \\
(0.022)\end{array}$ \\
\hline Employees & $\begin{array}{c}0.619^{* *} \\
(0.004)\end{array}$ & $\begin{array}{l}0.012^{* *} \\
(0.001)\end{array}$ & $\begin{array}{c}0.021^{* *} \\
(0.001)\end{array}$ \\
\hline Age & $\begin{array}{c}0.154^{* *} \\
(0.005)\end{array}$ & $\begin{array}{c}-0.005^{* *} \\
(0.001)\end{array}$ & $\begin{array}{c}-0.007^{* *} \\
(0.002)\end{array}$ \\
\hline Foreign Share & $\begin{array}{c}0.038^{* *} \\
(0.010)\end{array}$ & $\begin{array}{c}-0.001 \\
(0.005)\end{array}$ & $\begin{array}{c}-0.001 \\
(0.006)\end{array}$ \\
\hline Govt Share & $\begin{array}{c}-0.120^{* *} \\
(0.007)\end{array}$ & $\begin{array}{c}-0.015^{* *} \\
(0.002)\end{array}$ & $\begin{array}{c}-0.019 * * \\
(0.002)\end{array}$ \\
\hline Subsidy & $\begin{array}{l}0.068^{* *} \\
(0.003)\end{array}$ & $\begin{array}{l}0.012^{* *} \\
(0.001)\end{array}$ & $\begin{array}{c}0.015^{* *} \\
(0.002)\end{array}$ \\
\hline Markup & $\begin{array}{c}-0.007 \\
(0.012)\end{array}$ & $\begin{array}{c}0.001 \\
(0.001)\end{array}$ & $\begin{array}{c}0.001 \\
(0.001)\end{array}$ \\
\hline Observations & 818,232 & 839,550 & 839,550 \\
\hline
\end{tabular}

Notes: Dependent variable in column 1 is log TFP, in column 2 it is $\log ($ patents +1$)$, and in column 3 it is the inverse hyperbolic sine (IHS) transformation of patent counts. Estimations include firm and year fixed effects. Estimation sample includes domestically owned Chinese firms; JV firms, partner firms in JVs established prior to 1998, and majority foreign-owned firms are excluded. Robust standard errors clustered at the firm level reported in parentheses. ${ }^{* *} p<0.01,{ }^{*} p<0.05,{ }^{+} p<0.1$.

TFP effect, as columns 4 and 5 respectively indicate. We also investigate whether the size of the spillovers to JV partners changes upon including interaction variables that allow for the impact of JV formation to vary with particular firm characteristics. The final columns 6-9 of Table 7 indicate that JV spillovers to partners tend to be larger for relatively small, young, privately-owned, and not government-subsidized firms, respectively.

Another interesting question is whether the size of the spillovers to partners depends on the specific origin of the foreign investor in the JV. To examine this, we extend the DID equation (2) to incorporate two distinct partner spillover terms: one that is specific to a particular foreign source of the investment, and a second that captures investment from all other foreign sources:

$$
y_{i t}=\alpha+\beta_{1}\left[P T_{i} \times J V_{i t}^{C}\right]+\beta_{2}\left[P T_{i} \times J V_{i t}^{-C}\right]+\boldsymbol{X}_{i t}^{\prime} \gamma+\lambda_{i}+\mu_{t}+\varepsilon_{i t}
$$




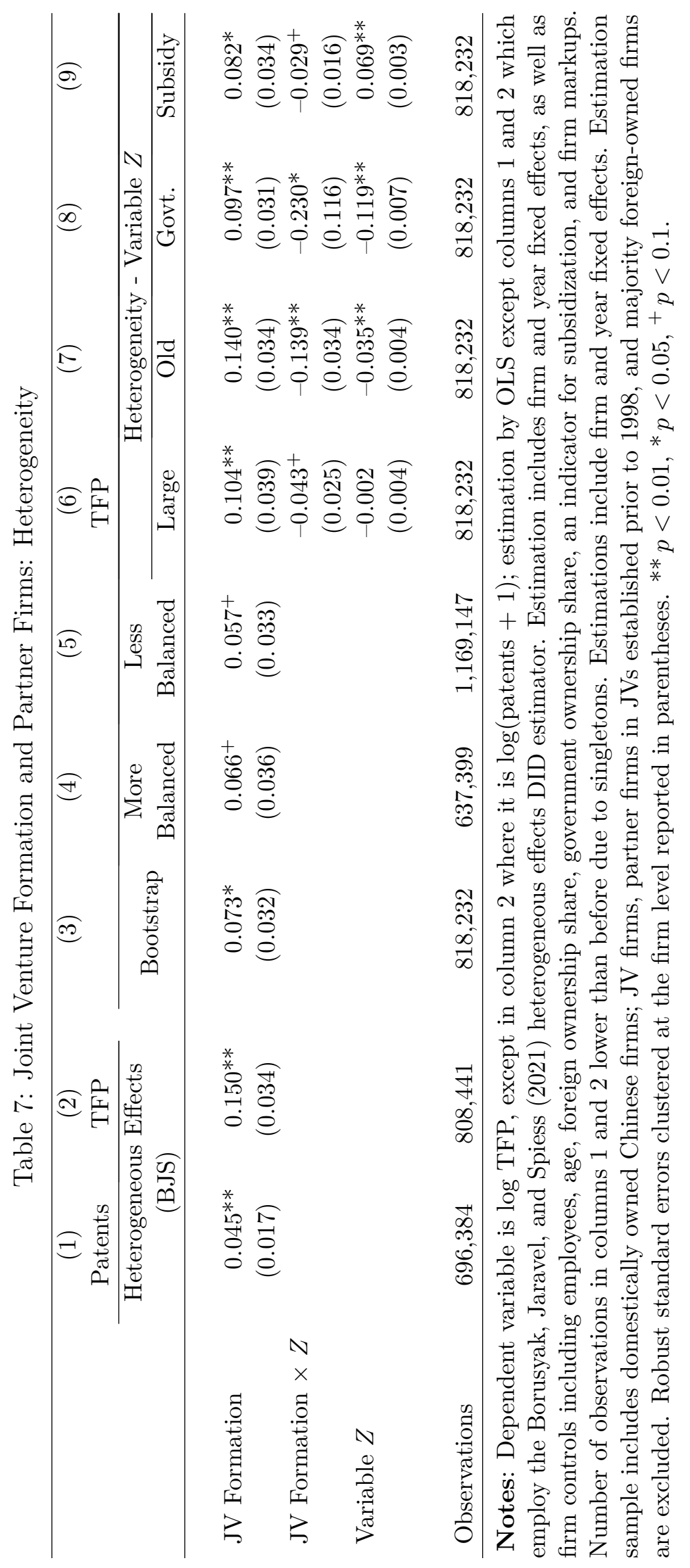


Table 8: Partner Spillovers and Investor Origin

\begin{tabular}{lccccc}
\hline & \multicolumn{2}{c}{ TFP } & & \multicolumn{2}{c}{ Patents } \\
\cline { 2 - 3 } \cline { 5 - 6 } Foreign Investor Origin & $(1)$ & $(2)$ & & $(3)$ & $(4)$ \\
\hline \multirow{2}{*}{ JV Formation - Origin } & USA & UK & & GER & HK \\
JV Formation - Other Origins & $0.130^{+}$ & $0.406^{* *}$ & & $0.209^{*}$ & $0.051^{+}$ \\
& $(0.074)$ & $(0.145)$ & & $(0.098)$ & $(0.026)$ \\
& 0.052 & 0.052 & & $0.057^{* *}$ & $0.073^{* *}$ \\
Observations & $(0.039)$ & $(0.039)$ & & $(0.020)$ & $(0.027)$ \\
& & & & & \\
\hline
\end{tabular}

Notes: Dependent variable is given at top of column. Estimation of equation (4). Estimation includes firm and year fixed effects, as well as firm controls including employees, age, foreign ownership share, government ownership share, an indicator for subsidization, and firm markups. Estimation sample includes domestically owned Chinese firms; JV firms, partner firms in JVs established prior to 1998, and majority foreign-owned firms are excluded. Robust standard errors clustered at the firm level reported in parentheses. ${ }^{* *} p<0.01,{ }^{*} p<0.05,{ }^{+} p<0.1$.

Here, $J V_{i t}^{C}$ is a time-varying indicator variable reflecting the formation of a JV formation for which $C$ (for instance, the United States) is the source of foreign investment in the JV. Similarly, $J V_{i t}^{-C}$ is an analogously defined indicator variable wherein $-C$ is the complement set of foreign JV origins (for instance, all JVs originating from sources besides the United States). Results for this analysis are shown in Table 8.

As can be seen in Table 8, we find evidence that JV spillovers to partners depend significantly on the source of the foreign investment in the cases of the United States, the United Kingdom, Germany, and Hong Kong. If the foreign investor is from either the United States or the United Kingdom, parent spillovers on firm productivity have a higher point estimate than parent spillovers generated from other sources of foreign investment, as can be seen in columns 1 and 2. According to our results, spillovers to JV partners are particularly large when the foreign investor originates from the United Kingdom. Spillovers to partners generated by JVs from either the United States or the United Kingdom are also particularly large in the sense that, when measuring the impacts of JVs not involving investors these countries, the coefficient on spillovers from other sources becomes insignificant at standard levels.

Furthermore, we find evidence that spillovers on parent innovation are relatively strong if the foreign investment comes from Germany; see column 3. In contrast, and as shown in column 4, we estimate a relatively smaller impact for partner spillovers for international investment originating from Hong Kong. Specifically, we obtain an estimate for spillovers involving international JVs with Hong Kong-based investors that is 5.1\% lower than either the point estimate for non-Hong Kong origins or from the average origin country (based on a comparison of the estimates found in column 
4 of Table 8 and those found in column 2 of 6$).{ }^{19}$ Overall, we estimate relatively strong parent spillovers if the foreign JV originates from a source that is relatively close to the technological frontier, such as the United States, the United Kingdom, or Germany. For countries that are situated below the world's technological frontier, we uncover less evidence for positive spillovers to JV partner firms. ${ }^{20}$

\subsection{Industry Spillovers from JVs}

We next turn to investigating whether JV formation also generates spillovers to other Chinese firms on top of those that accrue to Chinese JV partner firms. To this end we employ measures of horizontal and vertical spillovers as follows. The variable $J V_{j t}^{H}$ captures horizontal spillovers in the industry $j$ to which firm $i$ belongs, defined following the literature as

$$
J V_{j t}^{H}=\frac{\sum_{i \in j} J V \text { Firm }_{i} \times \text { Sales }_{i t}}{\sum_{i \in j} \text { Sales }_{i t}} .
$$

$J V$ Firm $_{i}$ is a (time-invariant) indicator variable that reflects whether firm $i$ was established under an international JV. The horizontal JV spillover variable therefore measures the fraction of sales that is accounted for by JVs in a given industry and year. This reflects the hypothesis that the higher is the prominence of JVs in an industry, the higher is the potential for positive learning externalities, for example through informal meetings of employees at local restaurants, exchanges at industry association conferences, and other channels.

In addition to investigating within-industry spillovers, we also assess whether JVs have generated learning externalities for firms in other industries (vertical spillovers). In the absence of information on explicit firm-to-firm links, we follow the standard approach and model these links using inputoutput tables. Backward joint venture spillovers (to firm $i$ ) in industry $j$ in year $t$ are defined as

$$
J V_{j t}^{B}=\sum_{k \neq j} \alpha_{k j} J V_{k t}^{H},
$$

where $\alpha_{k j}$ is the share of (non-final) output of industry $j$ that is sold as an input to industry $k$ (as obtained from the input-output tables published by China's NBS). For a given JV presence, $J V_{j t}^{H}$, these backward spillovers will be high when an industry's sales are biased towards industries in which JVs are important. The hypothesis is that supplying firms receive feedback from JV

\footnotetext{
${ }^{19}$ One reason why intergenerational spillovers originating from Hong Kong are lower than from other countries is the "roundtripping" noted above, i.e., that some of the FDI originating from Hong Kong is not as close to the world's technology frontier because in fact it originates from China.

${ }^{20}$ We have explored TFP and patenting spillovers to JV partners from all 27 origins that are represented in the sample, and Table 8 reports all cases for which we estimate significant coefficients for individual sources. However, given sampling variation, estimating origin-specific spillovers on JV partners from a particular source depends not only on how close to the technological frontier that source is, but also on the number of observations for JVs from that particular source that are present in our data.
} 
firms about performance standards, leading-edge procedures, and other knowledge to improve their processes and products (Iacovone, Javorcik, Keller, and Tybout, 2015 present analogous evidence for suppliers selling to Walmart).

Analogous to backward spillovers, we also consider forward spillovers in which JVs are the origin of inter-industry input flows. In particular, the forward spillover variable is defined as

$$
J V_{j t}^{F}=\sum_{k \neq j} \theta_{j k} J V_{k t}^{H}
$$

where $\theta_{j k}$ is the share of intermediate inputs of industry $j$ that is bought from industry $k$, with this information also taken from the NBS input-output tables. This forward spillover variable is high if an industry's inputs come disproportionately from industries in which JVs account for a large fraction of sales. For both horizontal and vertical spillovers, we also include an interaction term with an indicator variable for WTO membership, which is equal to one for years 2002 and later, and zero otherwise. This approach captures whether China's FDI liberalization and more generally the country's adoption of WTO rules led to changes in the extent of industry spillovers in the wake of WTO accession.

In the case of horizontal spillovers our specification becomes

$$
y_{i t}=\alpha+\beta_{1}\left[P T_{i} \times J V_{i t}\right]+\beta_{2} J V_{j t}^{H}+\beta_{3}\left[J V_{j t}^{H} \times W T O_{t}\right]+\boldsymbol{X}_{i t}^{\prime} \gamma+\lambda_{i}+\mu_{t}+\varepsilon_{i t}
$$

As in the preceding analysis, the dependent variable $y_{i t}$ is either firm TFP or patenting. Coefficient $\beta_{2}$ estimates horizontal JV spillovers in the years 1998-2001, while $\beta_{3}$ presents evidence on the change in these spillovers in China's WTO era. Horizontal and vertical spillovers are defined at the two-digit industry level. In addition to generating positive learning effects, JVs may also negatively affect other firms if joint ventures increase the degree of competition in the industry (Bloom, Schankerman, and Van Reenen, 2013). These effects are not externalities because they do not lead to a divergence of private from social net benefits. Table 9 shows the results.

The coefficient estimates in column 1 provide evidence that international JVs generate positive spillovers to Chinese firms in the same industry as evidenced by higher productivity. These effects have substantially increased following China's WTO accession. We also find support for the notion that industry productivity spillovers through vertical linkages, although it is weaker. Backward spillovers turn positive with China's WTO entry, as shown in column 2, while we find no evidence for forward productivity spillovers from JVs (column 3).

Patenting industry spillovers tend to be smaller than productivity spillovers in the pre-WTO era, as can be seen by comparing the results in columns $4-6$ to those in columns $1-3$. This may be 
Table 9: Industry Spillovers from International Joint Ventures

\begin{tabular}{|c|c|c|c|c|c|c|}
\hline & & TFP & & & Patents & \\
\hline & (1) & $(2)$ & $(3)$ & (4) & $(5)$ & (6) \\
\hline JV Formation & $0.063^{+}$ & $0.059^{+}$ & $0.063^{+}$ & $0.062^{* *}$ & $0.064^{* *}$ & $0.064^{* *}$ \\
\hline & $(0.035)$ & $(0.035)$ & $(0.035)$ & $(0.019)$ & $(0.019)$ & $(0.019)$ \\
\hline Horizontal JV & $0.942^{* *}$ & & & $-0.281^{* *}$ & & \\
\hline & $(0.103)$ & & & $(0.048)$ & & \\
\hline Horizontal JV $\times$ WTO & $0.541^{* *}$ & & & $0.377^{* *}$ & & \\
\hline & $(0.083)$ & & & $(0.037)$ & & \\
\hline Backward JV & & $-0.180^{*}$ & & & -0.005 & \\
\hline & & $(0.072)$ & & & $(0.026)$ & \\
\hline Backward JV × WTO & & $1.327^{* *}$ & & & $0.187^{* *}$ & \\
\hline & & $(0.077)$ & & & $(0.029)$ & \\
\hline Forward JV & & & $-0.626^{*}$ & & & $-0.756^{* *}$ \\
\hline & & & $(0.283)$ & & & $(0.109)$ \\
\hline Forward JV $\times$ WTO & & & -0.186 & & & $0.355^{* *}$ \\
\hline & & & $(0.243)$ & & & $(0.090)$ \\
\hline Observations & 797,005 & 797,005 & 797,005 & 684,484 & 684,484 & 684,484 \\
\hline
\end{tabular}


due to competition effects as firms race to obtain certain patents. At the same time, we see that all forms of industry spillovers from JVs on patenting have become more positive with China's entry into the WTO, and they are positive overall in the case of horizontal and backward spillovers. It is important to note that these industry spillovers arise on top of the spillovers to Chinese partner firms, as evidenced by the virtually unchanged positive coefficient on JV Formation in all specifications shown in Table $9 .^{21}$

\subsection{Additional Factors}

We next investigate a number of other developments in China that occurred during the country's WTO accession to assess whether our baseline findings are indeed driven by technological spillovers from international JVs, or rather, these other contemporaneously changing factors. While our results so far document significant changes in the magnitude of the technological spillovers from international JVs to other domestic Chinese firms as China entered the WTO, the extent to which these effects were economy-wide or industry-specific has not yet been made clear. To explore these considerations, we analyze three major changes in the Chinese economy that took place during the sample period.

First, the liberalization of China's foreign investment regime with the country's entry into the WTO entailed significant differential changes in restrictions on FDI across industries. To account for the impact of these changes, we employ detailed industry information on which sectors experienced the most comprehensive liberalization, versus sectors that were less strongly liberalized. Information on these changes is obtained from the foreign investment Catalogue discussed in Section 2 above. Second and relatedly, China's WTO accession went hand in hand with widespread reductions in its import tariffs. We therefore explore whether differential trade liberalization across industries during this period was a key factor in enhancing firm performance by incorporating information on industry-level changes in import tariffs. Third and finally, we note that China undertook many large-scale structural economic reforms during this period, one of the most significant outcomes of which was the privatization of many state-owned enterprises (SOEs). To capture this decline in the extent of state ownership in many Chinese industries, we explore whether accounting for changes in ownership structure within industries meaningfully impacts our findings on JV spillovers.

Table 10 presents the results of these three analyses, with the results on TFP shown in columns 1-3 and the results on patenting shown in columns 4-6. In column 1, we explore the extent to which the differential liberalization of FDI regulations affected the productivity of domestic Chinese firms. To

\footnotetext{
${ }^{21}$ We have also explored further extending this analysis in a way that flexibly accounts for additional changes occurring during China's WTO accession that may have affected firm outcomes. Specifically, we have estimated additional specifications in which our key firm characteristics (share of government ownership, number of employees, and subsidization) are interacted with the post-2002 (WTO) indicator. Overall, the results of this analysis demonstrate that our findings on JV formation in China cannot be attributed to changes in other factors that occurred the early 2000s such as government ownership, firm size, or the degree of subsidization.
} 


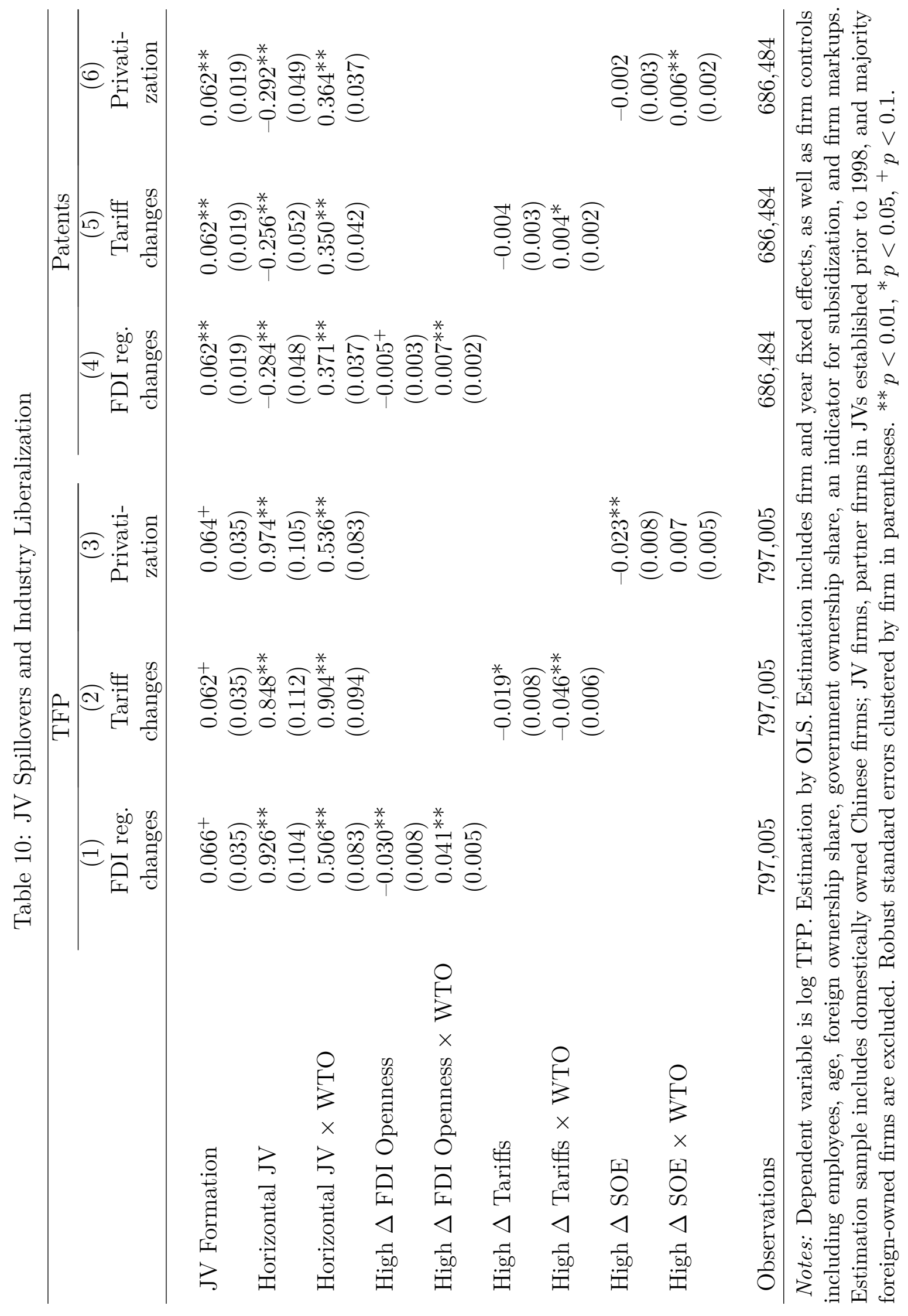


do this, we create an indicator variable "High $\Delta$ FDI Openness" which is equal to one if a (two-digit) industry is above median in terms of the liberalization of activities (changing from prohibited to restricted, or from restricted to encouraged, etc.) to foreign investors. We then interact this variable with the WTO indicator as an additional regressor. The industry liberalization measure enters with a negative coefficient, while its interaction with the WTO indicator enters with a positive coefficient. This indicates that firms in industries which saw relatively comprehensive liberalization between 1998 and 2002 gain disproportionately in terms of productivity. At the same time, the impact of including these variables on our JV spillover results is limited, with the estimate on $J V$ Formation remaining unchanged, and the post-WTO horizontal spillover coefficient now estimated at 0.506 compared to 0.541 before.

Columns 2 and 3 augment the specification with an indicator for high rates of tariff changes and privatization, respectively. The former is based on the indicator variable "High $\Delta$ Tariffs," which is equal to one for industries that experienced an above-median (in terms of magnitude) reduction in China's average import tariffs during the 1998-2002 (pre-WTO) period. The latter introduces the indicator variable "High $\triangle \mathrm{SOE}$," which similarly reflects industries that underwent an above-median (again, in terms of magnitude) reduction in the total ownership share of stateowned enterprises within industries during the 1998-2002 period. Accounting for differences in WTO-mandated tariff changes increases the size of post-2002 JV spillovers somewhat (column 3), though the sign and significance of the results on this variable remain the the same. We find little evidence that privatizations are related to the size of JV spillovers (column 4).

We repeat these three analyses for analysis estimates of JV spillovers on firm patenting, the results for which are shown in columns 4-6 of Table 10. In line with our findings on firm productivity, we find little evidence that our estimates are significantly affected by accounting for these other factors. Consequently, we do not find any support for the notion that our results on productivity spillovers were instead mediated by other changes taking place in China's economy during the early 2000s. Overall, these results suggest that the dynamics of technological learning externalities are more closely related to the aggregate, rather than industry-specific, changes that took place during China's WTO accession.

\subsection{Further Discussion}

We estimate that upon JV formation, the typical Chinese partner firm experiences an increase in patenting by about 5 and productivity gains between 6 and 15 percent. These are sizable effects. Moreover, our heterogeneity analysis shows that spillovers to Chinese partner firms are captured primarily by relatively young and small Chinese firms that are privately owned and do not receive

subsidies from the government. Furthermore, Chinese partner firm spillovers are particularly large in the case of FDI coming from the United Kingdom, Germany, and the United States, countries 
which are close to the world's technological frontier. To the best of our knowledge, this paper presents the first quantitative analysis of spillovers from international JVs to domestic partner firms.

We also find evidence for both positive horizontal and backward productivity spillovers from JV formation. Furthermore, China's entry into the WTO has increased patenting through horizontal and backward JV spillovers. To the best of our knowledge, there are no large-scale quantitative studies to which our results can be compared, particularly as relating to spillovers originating from international JVs.

Why did learning externalities from JVs increasing as China drops JV requirements, liberalized its FDI and trade regimes, and improved the protection of IPRs? First of all, the size of JV learning externalities and the degree of formal IPR protection are not flip sides of the same coin. Technological learning externalities that arise when JV employees interact with workers from other firms in the same industry at restaurants or conferences are not the same as formal IPR violations that could be litigated at the WTO. A second reason for larger JV spillovers in the WTO era is that China has become more important as a location of technological excellence compared to the pre-WTO era. To the extent that knowledge diffusion is facilitated by agglomeration, this factor increases the scope of learning externalities. Finally, by becoming a member of a multilateral trade and investment agreement China has shifted expectations about its future policies, tilting them towards "rules" rather than "discretion." Put differently, WTO membership serves as a credible commitment which has increased the incentives for foreign investors to bring their most advanced technology to China.

Turning to the economic significance of our industry spillover findings, a simple back-of-the-envelope calculation gives the following results. The mean of the horizontal spillover variable is 5 percent in 1998-2001, falling to an average of 4 percent during the post-2002 subsample. The coefficients in the TFP equation (column 1 of Table 9) for the first and the second subperiod are roughly 0.9 and 1.5, respectively. This means that horizontal JV spillovers account for about 5 percent of the increase in average productivity between 1998 to 2007. Thus, horizontal JV spillovers explain a sizable fraction of TFP growth.

\section{Conclusions}

International JVs comprise a major channel for FDI, particularly for multinationals that establish operations in China. The effects of international JV formation are multifaceted, and we delineate our analysis in several ways. Importantly, our empirical approach allows us to distinguish the Chinese firm forming the JV from the newly set-up JV firm itself in a comprehensive dataset of Chinese firms. We have investigated the attributes of firms, including market share, stock 
of technology, or regulatory expertise, that are conducive to being picked as Chinese partners to foreign investors seeking to enter the Chinese market. Generally, foreign investors seek out profitable, large, and highly productive firms, as well as firms that demonstrate high rates of export participation and patenting. Firms that receive government subsidies - implicitly, those firms with well-developed political connections - also tend to be more likely to be chosen as JV partners. While the existing literature has explored such issues in partner choice, the fact that we approach the question with a novel dataset in an econometric framework deepens our understanding of the empirical determinants of selection.

We then explore the effects that materialize subsequent to the creation of the JV on the domestic JV partner as well as other Chinese firms. We find evidence for the existence of indirect technology transfer, a phenomenon that we call intergenerational technology transfer, wherein the domestic JV partners perform better after the inception. We find that these effects are strongest for partners in JVs established foreign investors from the United States, the United Kingdom, and Germany, multinationals from which are typically at the forefront of the technological frontier. We also show that JV firms generate positive externalities to other domestic firms that operate in the same industry (horizontal spillovers). Moreover, we find that Chinese firms that disproportionately sell to international JVs experience increases in their productivity and patenting (backward spillovers). These findings suggest that technological externalities from JVs are systematically present both within and beyond the confines of the JV.

Ultimately, international JVs occupy an important role in the arena of foreign investment. Based on our findings, the unique nature of such arrangements between domestic firms and foreign partners generates far-reaching impacts that manifest themselves both for partner firms as well as firms outside the JV. The literature on multinationals has expended significant effort in quantifying the effects of FDI; however, the specific role of JVs has remained underexplored, and our analysis is only a first step to address this. Our results serve to inform a broader understanding of effective foreign investment policy.

As China has liberalized its foreign investment environment, encouraging the establishment of WFOEs and opening more sectors to foreign entry, the ensuing reduction in the utilization of JVs promises to impact the way in which knowledge is transmitted between firms. While channels for learning and technology transfer might arise from WFOEs (perhaps via labor turnover, intermediate input sourcing, or broader learning effects), the fact that domestic firms play no direct role in this type of investment shuts down the potential international technology transfer effects revealed in JVs firms and the intergenerational effects accruing to partner firms. Additionally, WFOEs are likely to be better equipped to safeguard their intellectual property and proprietary technologies from being disseminated to domestic firms, dampening the innovation externalities that we find evidence for, while potentially sapping market share from domestic competitors - in other words, 
the move away from international JVs might amplify the negatives and attenuate the positives arising from foreign investment. 


\section{References}

Ackerberg, D., C. L. Benkard, S. Berry, and A. Pakes (2007). Econometric Tools for Analyzing Market Outcomes. Handbook of Econometrics Volume 6A. J. Heckman and E. Leamer (eds.), Amsterdam: North Holland, 4172-4276.

Alfaro-Urena, A., I. Manelici, and J. Vasquez (2022). The Effects of Joining Multinational Supply Chains: New Evidence from Firm-to-Firm Linkages. The Quarterly Journal of Economics 137(3), $1495-1552$.

Bloom, N., M. Schankerman, and J. Van Reenen (2013). Identifying Technology Spillovers and Product Market Rivalry. Econometrica 81 (4), 1347-1393.

Borusyak, K., X. Jaravel, and J. Spiess (2021). Revisiting Event Study Designs: Robust and Efficient Estimation. CEPR Discussion Paper 17247.

Brandt, L., T. Rawski, and J. Sutton (2008). China's Industrial Development. China's Great Economic Transformation, 569-632.

Brandt, L., J. Van Biesebroeck, and Y. Zhang (2012). Creative Accounting or Creative Destruction? Firm-Level Productivity Growth in Chinese Manufacturing. Journal of Development Economics 97(2), 339-351.

Brandt, L., J. Van Biesebroeck, and Y. Zhang (2014). Challenges of Working with the Chinese NBS Firm-Level Data. China Economic Review 30, 339-352.

De Loecker, J., J. Eeckhout, and G. Unger (2020). The Rise of Market Power and The Macroeconomic Implications. The Quarterly Journal of Economics 135(2), 561-644.

DNEA (1999). Input-Output Table of China 1997. Department of National Economic Accounts. Beijing: China Statistical Publishing House.

DNEA (2005). Input-Output Table of China 2002. Department of National Economic Accounts. Beijing: China Statistical Publishing House.

DNEA (2007). Input-Output Table of China 2005. Department of National Economic Accounts. Beijing: China Statistical Publishing House.

DNEA (2009). Input-Output Table of China 2007. Department of National Economic Accounts. Beijing: China Statistical Publishing House.

Farhooman, A., Z. Tao, I. Wang, and L. Yi (2005). Shanghai Volkswagen: Time for a Radical Shift of Gears. Asia Case Research Centre, Hong Kong University.

Goodman-Bacon, A. (2021). Difference-in-differences with variation in treatment timing. Journal of Econometrics 225, 254-277.

Handley, K. and N. Limão (2015). Trade and Investment under Policy Uncertainty: Theory and Firm Evidence. American Economic Journal: Economic Policy 7(4), 189-222.

Howell, S. (2018). Joint Ventures and Technology Adoption: A Chinese Industrial Policy That Backfired. Research Policy 47(8), 1448-1462. 
Hsieh, C.-T. and P. Klenow (2009). Misallocation and Manufacturing TFP in China and India. The Quarterly Journal of Economics 124(4), 1403-1448.

Hu, A. and G. Jefferson (2002). FDI Impact and Spillovers: Evidence from China's Electronic and Textile Industries. The World Economy 25(8), 1063-1076.

Huang, T. (2004). Spillovers from Taiwan, Hong Kong, and Macau Investment and from Other Foreign Investment in Chinese Industries. Contemporary Economic Policy 22(1), 13-25.

Iacovone, L., B. Javorcik, W. Keller, and J. Tybout (2015). Supplier Responses to Walmart's Invasion in Mexico. Journal of International Economics 95(1), 1-15.

Javorcik, B. (2004). Does Foreign Direct Investment Increase the Productivity of Domestic Firms? In Search of Spillovers through Backward Linkages. The American Economic Review 94 (3), 605-627.

Javorcik, B. and M. Spatareanu (2009). Do Czech Suppliers Learn from Their Relationships with Multinationals? The Scandinavian Journal of Economics 111(4), 811-833.

Jiang, K., W. Keller, L. D. Qiu, and W. Ridley (2019). Estimates of Total Factor Productivity from the ASIF Panel. Mimeo, University of Colorado.

Keller, W. (2022). Knowledge spillovers, international trade, and foreign direct investment. Oxford Research Encyclopedia of Economics and Finance. Oxford University Press.

Lardy, N. (2001). Issues in China's WTO Accession. Washington: Brookings Institution Press.

Lu, Y., Z. Tao, and L. Zhu (2017). Identifying FDI Spillovers. Journal of International Economics 10\%, 75-90.

National Bureau of Statistics (2009). China Urban Life and Price Yearbook. China Statistics Press.

OECD (2000). Main Determinants and Impacts of Foreign Direct Investment on China's Economy. OECD Working Papers on International Investment, 2000/04, OECD Publishing.

Olley, S. and A. Pakes (1996). The Dynamics of Productivity in the Telecommunications Equipment Industry. Econometrica 64(6), 1263-1297.

Orr, S., D. Trefler, and M. Yu (2018). Estimating Productivity Using Chinese Data: Methods, Challenges, and Results. In World Trade Evolution, Routledge, 229-260.

Pierce, J. and P. Schott (2016). The Surprisingly Swift Decline of US Manufacturing Employment. The American Economic Review 106(7), 1632-1662.

Tao, Z. and E. Ho (2005). Shanghai General Motors: The Rise of a Late-Comer. Asia Case Research Centre, Hong Kong University.

UNCTAD (2003). World Investment Report. United Nations Conference on Trade and Development, Geneva.

USTR (2017). 2017 Report to Congress On China's WTO Compliance. Office of the United States Trade Representative. Available at https://ustr.gov/sites/default/files/USTR\%20301\% 20 Fact $\% 20$ Sheet.pdf. 
USTR (2018). Section 301 Fact Sheet. Office of the United States Trade Representative. Available at https://ustr.gov/about-us/policy-offices/press-office/fact-sheets/2018/ march/section-301-fact-sheet.

Van Biesebroeck, J. (2007). Robustness of Productivity Estimates. The Journal of Industrial Economics LV(3), 529-569.

Van Reenen, J. and L. Yueh (2012). Why Has China Grown so Fast? The Role of International Technology Transfer. CEP Discussion Paper 1121.

Wei, Y. and X. Liu (2006). Productivity Spillovers from R\&D, Exports and FDI in China's Manufacturing Sector. Journal of International Business Studies 37(4), 544-557.

Wooldridge, J. (2009). On Estimating Firm-level Production Functions Using Proxy Variables to Control for Unobservables. Economics Letters 104(3), 112-114. 
Online Appendix - To be published only if requested 


\section{Appendix A. Data}

\section{TFP Estimation}

We employ information in the ASIF database to estimate the total factor productivity (TFP) of a firm. Ackerberg, Benkard, Berry, and Pakes (2007) discuss some of the major challenges to TFP estimation. Furthermore, it is well-known that different methods of estimating TFP can be more or less affected by the specific characteristics of the data (Van Biesebroeck, 2007). In this analysis we restrict our attention to semi-parametric estimators using control functions. In the area of productivity estimation the groundbreaking contribution is (Olley and Pakes, 1996) (OP for short), from which a number of additional influential approaches have followed (including that of Wooldridge, 2009). The following description focuses on the method of Olley and Pakes (1996). For more information the interested reader should consult the original papers. To ensure robustness, we have employed ten different TFP estimators using a control function approach and information from the ASIF database; these results are summarized in Jiang, Keller, Qiu, and Ridley (2019).

In the presence of selection bias and simultaneity, OP estimation allows for endogeneity between firms' input choices and the unobserved productivity differences among firms. Such estimation also considers the exit of firms from the market; hence, this method has several advantages over OLS. The OP method is characterized by a Bellman equation and assumes that the firm constantly maximizes the expected discounted value of future profits; thus, stay-or-quit and investment decisions are formulated in each time period. In the OP approach one uses investment as a proxy for unobservable productivity shocks. A semi-parametric method is applied to control for both the simultaneity caused by these unobserved shocks and non-random sample selection induced by the differing exit probabilities for small and large low-productivity firms.

We assume that output is produced with capital $(K)$, labor $(L)$, and materials $(M)$ using a Cobb-Douglas production function:

$$
Y_{i t}=F\left(L_{i t}, K_{i t}, M_{i t}, \Omega_{i t}\right)
$$

The term $\Omega_{i t}$ is an unobserved firm-specific productivity shifter that will serve as the control variable. Alternatively, we consider value added, given by

$$
Y_{i t}=F\left(L_{i t}, K_{i t}, \Omega_{i t}\right)
$$

The following exposition focuses for brevity on the OP approach using value added as the measure of output. 
Taking logs and adding an error term we obtain

$$
y_{i t}=\beta_{0}+\beta_{1} l_{i t}+\beta_{2} k_{i t}+\omega_{i t}+\varepsilon_{i t},
$$

where $y_{i t}$ is the $\log$ of value added for firm $i$ in period $t, l_{i t}$ is the log of labor input by firm $i$ in year $t$ (measured by the number of employees), $k_{i t}$ is the log of the capital input by firm $i$ in year $t$, $\omega_{i t}$ is the productivity known by a firm when it makes its liquidation and investment decisions, and $\varepsilon_{i t}$ is the error term. Both $\omega_{i t}$ and $\varepsilon_{i t}$ are unobservable to the econometrician; nonetheless, $\omega_{i t}$ affects a firm's input decision as a state variable in the firm's decision whereas $\varepsilon_{i t}$ does not.

Employing OP we assume that expected productivity is a function of current productivity and capital, that is, $\mathrm{E}\left[\omega_{i t+1} \mid \omega_{i t}, k_{i t}\right] . \omega_{i t}$ is assumed to follow a first-order Markov process. Given these modeling assumptions, OLS estimation is biased for two reasons: first, the capital input is correlated with productivity. When the firm's manager observes a positive productivity shock she will increase investment. Second, there is survival bias, because larger firms are less likely to exit the market than smaller firms.

We conduct our estimation process in three steps. In step one, assuming that investment of firm $i$ at time $t\left(I_{i t}\right)$ is strictly positive, the relationship between productivity and investment (as well as capital) can be inverted to back out the unobserved term $\omega_{i t}$ :

$$
\omega_{i t}=I^{-1}\left(I_{i t}, K_{i t}\right)=h\left(I_{i t}, K_{i t}\right)
$$

Using this result, the production function can be rewritten as

$$
y_{i t}=\beta_{1} l_{i t}+\Phi\left(i_{i t}, k_{i t}\right)+\varepsilon_{i t},
$$

where $\Phi\left(i_{i t}, k_{i t}\right)=\beta_{0}+\beta_{2} k_{i t}+h\left(i_{i t}, k_{i t}\right)$. We approximate $\Phi(\cdot)$ with a second-order polynomial series in investment and capital. The partially linear equation described above can be estimated by OLS, and the estimation of $\beta_{1}$ is consistent because $\Phi\left(i_{i t}, k_{i t}\right)$ controls for the unobserved productivity. In the second step, we control for survival bias using a limited-dependent variable regression, which can be used to estimate the capital elasticity, $\beta_{2}$. The probability of survival in period $t$ depends on the productivity in period $t-1$, which is in turn dependent on the capital and investment in period $t-1$. The predicted probability of survival is denoted by $\hat{P}_{i t}$. In the third and final step, we estimate $\beta_{2}$ using the following equation:

$$
y_{i t}-\widehat{\beta}_{1} l_{i t}=\beta_{2} k_{i t}+g\left(\widehat{\Phi}_{t-1}-\beta_{2} k_{i t-1}, \widehat{P}_{i t}\right)+\varepsilon_{i t}
$$

where $g(\cdot)$ is approximated by a second-order polynomial in $\widehat{\Phi}_{t-1}-\beta_{2} k_{i t-1}$ and $\widehat{P}_{i t}$, and $\widehat{\beta}_{1}$ is the consistent estimate of the labor elasticity from step one. 
The measure of output in the ASIF is deflated by the producer price index for manufactured products. We employ standard assumptions and the perpetual inventory method (PIM) to construct measures of firms' capital stocks. Specifically, the effective capital stock in production is measured as a weighted sum of previous fixed asset investments in constant price term:

$$
R C S_{t}=\sum_{t=0}^{\infty} d_{\tau} I_{t-\tau}
$$

where $R C S_{t}$ is real capital stock in year $t, d_{\tau}$ is the efficiency of a fixed asset in the $\tau$ th year, and $I_{t-\tau}$ is the fixed asset investment flow $\tau$ years ago. With the additional assumption that $d_{\tau}$ declines geometrically, i.e. $d_{\tau}=(1-\delta)^{\tau}$, the PIM equation can be written as

$$
R C S_{t}=R C S_{t-1}+I_{t}-\delta R C S_{t-1}
$$

We recursively calculate fixed asset growth at the two-digit SIC code level as a recursive step back to the year when a firm was established. Investment deflators are obtained from the China Urban Life and Price Yearbook (2009) published by China's National Bureau of Statistics. The year 1978 is chosen as the starting point of the initial capital stock for series calculation, and we follow Brandt, Van Biesebroeck, and Zhang (2012) and Hsieh and Klenow (2009) who apply $9 \%$ as the depreciation rate to calculate the TFP of Chinese firms. The assumed depreciation rate is a chain-linked price deflator calculated by Brandt, Rawski, and Sutton (2008) based on separate price indices for equipment, machinery, and buildings/structures as well as the shares of these items in fixed assets, as reported by the National Bureau of Statistics.

Using this approach at the two-digit industry level, we find average labor shares in value added ranging from 0.43 (CIC 25) to 0.78 (CIC 14), and capital shares in value added ranging from 0.27 (CIC 24) to 0.54 (CIC 15). The assumption of constant returns to scale can typically not be rejected. Comparing TFP based on gross output with those based on value added we found the former to yield more plausible firm-level estimates. This confirms similar findings based on the ASIF by Orr, Trefler, and Yu (2018). Consequently, both the Olley and Pakes (1996) and Wooldridge (2009) based TFP estimates employed in this paper are calculated based on gross output. 


\section{Regional Distribution of International JVs in China}

Table A1: Number of International JVs in Sample by Region and Year, 1998-2007

\begin{tabular}{|c|c|c|c|c|c|c|c|c|c|c|}
\hline \multirow[b]{2}{*}{ Region } & \multicolumn{10}{|c|}{ Number of International JV firms } \\
\hline & 1998 & 1999 & 2000 & 2001 & 2002 & 2003 & 2004 & 2005 & 2006 & 2007 \\
\hline Anhui & 17 & 21 & 26 & 30 & 32 & 31 & 33 & 31 & 29 & 28 \\
\hline Beijing & 149 & 167 & 177 & 194 & 192 & 190 & 197 & 187 & 179 & 167 \\
\hline Chongqing & 23 & 30 & 31 & 40 & 41 & 40 & 35 & 34 & 34 & 33 \\
\hline Fujian & 18 & 110 & 116 & 130 & 138 & 137 & 137 & 128 & 125 & 114 \\
\hline Gansu & 0 & 6 & 6 & 6 & 6 & 8 & 6 & 6 & 6 & 5 \\
\hline Guangdong & 286 & 344 & 382 & 451 & 481 & 493 & 473 & 441 & 414 & 390 \\
\hline Guangxi & 16 & 16 & 17 & 21 & 25 & 30 & 30 & 28 & 26 & 25 \\
\hline Guizhou & 10 & 13 & 13 & 15 & 16 & 16 & 15 & 15 & 14 & 13 \\
\hline Hainan & 6 & 6 & 6 & 6 & 6 & 5 & 5 & 4 & 4 & 3 \\
\hline Hebei & 57 & 68 & 74 & 86 & 90 & 86 & 71 & 70 & 66 & 57 \\
\hline Heilongjiang & 22 & 25 & 27 & 30 & 31 & 29 & 23 & 20 & 18 & 17 \\
\hline Henan & 28 & 34 & 34 & 39 & 36 & 41 & 35 & 32 & 29 & 25 \\
\hline Hubei & 44 & 50 & 47 & 58 & 58 & 53 & 45 & 44 & 42 & 41 \\
\hline Hunan & 10 & 11 & 14 & 21 & 25 & 25 & 28 & 25 & 27 & 26 \\
\hline Jiangsu & 236 & 255 & 296 & 367 & 403 & 418 & 388 & 366 & 349 & 337 \\
\hline Jiangxi & 5 & 7 & 10 & 12 & 14 & 13 & 12 & 11 & 11 & 10 \\
\hline Jilin & 0 & 25 & 30 & 32 & 34 & 30 & 29 & 27 & 25 & 26 \\
\hline Liaoning & 83 & 93 & 110 & 119 & 128 & 143 & 142 & 133 & 127 & 120 \\
\hline Nei Mongol & 6 & 6 & 8 & 9 & 11 & 13 & 12 & 12 & 11 & 10 \\
\hline Ningxia Hui & 0 & 1 & 1 & 1 & 1 & 1 & 1 & 1 & 1 & 1 \\
\hline Qinghai & 2 & 2 & 2 & 2 & 4 & 4 & 3 & 3 & 1 & 2 \\
\hline Shaanxi & 10 & 22 & 23 & 24 & 25 & 26 & 19 & 18 & 15 & 12 \\
\hline Shandong & 116 & 131 & 143 & 181 & 212 & 237 & 217 & 208 & 200 & 182 \\
\hline Shanghai & 407 & 452 & 477 & 522 & 543 & 538 & 508 & 481 & 454 & 427 \\
\hline Shanxi & 10 & 14 & 16 & 17 & 20 & 18 & 17 & 14 & 12 & 11 \\
\hline Sichuan & 34 & 34 & 44 & 47 & 55 & 53 & 56 & 54 & 52 & 51 \\
\hline Tianjin & 122 & 156 & 165 & 175 & 172 & 164 & 166 & 157 & 145 & 138 \\
\hline Xinjiang & 5 & 4 & 5 & 6 & 5 & 6 & 6 & 6 & 5 & 5 \\
\hline Yunnan & 21 & 22 & 22 & 27 & 27 & 24 & 22 & 21 & 20 & 19 \\
\hline Zhejiang & 148 & 165 & 227 & 319 & 359 & 370 & 367 & 345 & 326 & 312 \\
\hline Total & 1,891 & 2,290 & 2,549 & 2,987 & 3,190 & 3,242 & 3,098 & 2,922 & 2,767 & 2,607 \\
\hline
\end{tabular}




\section{Industry Composition of the Sample}

Table A2: Two-Digit CIC Industry Distribution of the Sample by Firm Type

\begin{tabular}{|c|c|c|c|c|c|c|}
\hline \multirow[b]{2}{*}{ CIC Industry } & \multicolumn{2}{|c|}{$\begin{array}{l}\text { Domestic } \\
\text { Firms }\end{array}$} & \multicolumn{2}{|c|}{$\begin{array}{c}\text { Joint } \\
\text { Ventures }\end{array}$} & \multicolumn{2}{|c|}{$\begin{array}{l}\text { Partner } \\
\text { Firms }\end{array}$} \\
\hline & Obs. & $\%$ & Obs. & $\%$ & Obs. & $\%$ \\
\hline 13 Food processing & 47,730 & 6.17 & 789 & 2.86 & 6,261 & 4.55 \\
\hline 14 Food manufacturing & 19,408 & 2.51 & 649 & 2.36 & 3,989 & 2.9 \\
\hline 15 Beverage manufacturing & 14,514 & 1.88 & 614 & 2.23 & 2,047 & 1.49 \\
\hline 16 Tobacco processing & 1,489 & 0.19 & 35 & 0.13 & 197 & 0.14 \\
\hline 17 Textiles & 61,669 & 7.98 & 2,106 & 7.65 & 11,874 & 8.63 \\
\hline 18 Apparel & 27,442 & 3.55 & 1,586 & 5.76 & 12,295 & 8.94 \\
\hline 19 Leather and fur products & 13,761 & 1.78 & 620 & 2.25 & 5,454 & 3.97 \\
\hline 20 Wood products and processing & 11,633 & 1.50 & 443 & 1.61 & 2,229 & 1.62 \\
\hline 21 Furniture & 6,914 & 0.89 & 266 & 0.97 & 1,802 & 1.31 \\
\hline 22 Paper and paper products & 26,775 & 3.46 & 578 & 2.10 & 3,153 & 2.29 \\
\hline $\begin{array}{l}23 \text { Printing and reproduction of } \\
\text { recorded media }\end{array}$ & 19,926 & 2.58 & 605 & 2.20 & 3,134 & 2.28 \\
\hline $\begin{array}{l}24 \text { Cultural, educational, and } \\
\text { sporting goods }\end{array}$ & 7,330 & 0.95 & 488 & 1.77 & 3,317 & 2.41 \\
\hline $\begin{array}{l}25 \text { Processing of petroleum, coking, } \\
\text { and nuclear fuel production }\end{array}$ & 5,537 & 0.72 & 83 & 0.30 & 691 & 0.50 \\
\hline $\begin{array}{l}26 \text { Raw chemicals and chemical } \\
\text { products }\end{array}$ & 65,089 & 8.42 & 2,048 & 7.44 & 8,863 & 6.44 \\
\hline 27 Pharmaceuticals & 19,306 & 2.50 & 843 & 3.06 & 3,847 & 2.80 \\
\hline 28 Chemical fiber & 4,070 & 0.53 & 236 & 0.86 & 889 & 0.65 \\
\hline 29 Rubber products & 9,608 & 1.24 & 335 & 1.22 & 1,610 & 1.17 \\
\hline 30 Plastic products & 31,415 & 4.06 & 1,237 & 4.49 & 7,805 & 5.68 \\
\hline 31 Non-metallic mineral products & 80,621 & 10.43 & 1,361 & 4.94 & 7,959 & 5.79 \\
\hline $\begin{array}{l}32 \text { Production and processing of } \\
\text { ferrous metals }\end{array}$ & 18,381 & 2.38 & 279 & 1.01 & 1,431 & 1.04 \\
\hline $\begin{array}{l}33 \text { Production and processing of } \\
\text { non-ferrous metals }\end{array}$ & 15,046 & 1.95 & 396 & 1.44 & 1,703 & 1.24 \\
\hline 34 Metal products & 42,512 & 5.50 & 1,315 & 4.77 & 7,184 & 5.22 \\
\hline 35 General purpose machinery & 62,625 & 8.10 & 1,825 & 6.63 & 7,016 & 5.10 \\
\hline 36 Special purpose machinery & 35,011 & 4.53 & 1,020 & 3.70 & 4,278 & 3.11 \\
\hline 37 Transportation equipment & 39,253 & 5.08 & 1,831 & 6.65 & 5,116 & 3.72 \\
\hline $\begin{array}{l}39 \text { Electrical machinery and } \\
\text { equipment }\end{array}$ & 46,954 & 6.07 & 2,295 & 8.33 & 8,332 & 6.06 \\
\hline $\begin{array}{l}40 \text { Communication, computer, and } \\
\text { electronic equipment }\end{array}$ & 15,846 & 2.05 & 2,397 & 8.70 & 7,883 & 5.73 \\
\hline $\begin{array}{l}41 \text { Measuring, analyzing, and } \\
\text { controlling instruments }\end{array}$ & 9,197 & 1.19 & 801 & 2.91 & 2,968 & 2.16 \\
\hline 42 Miscellaneous manufacturing & 14,155 & 1.83 & 462 & 1.68 & 4,206 & 3.06 \\
\hline & 773,217 & 100 & 27,543 & 100 & 137,533 & 100 \\
\hline
\end{tabular}




\section{FDI Restrictiveness Index by Industry}

The following presents details on the change in FDI restrictiveness based on the number of activities that are (i) Encouraged, (ii) Restricted, and (iii) Prohibited at the level of two-digit industries, based on China's Catalogue for Guidance of Foreign Investment Industries. We focus on the change between 1998 and 2002 as opposed to a later year because the 2002 changes were specified as conditions for China's entry into the WTO, and as a consequence, they are more plausibly exogenous. 
Table A3: FDI Restrictiveness by Industry, 1998 to 2002

\begin{tabular}{|c|c|c|c|c|c|c|c|c|}
\hline \multirow[b]{3}{*}{ CIC Industry } & \multicolumn{6}{|c|}{ Number of Activities Classified As } & \multirow{3}{*}{$\begin{array}{l}\text { Mean } \\
\text { Change }\end{array}$} & \multirow{3}{*}{$\begin{array}{c}\Delta \mathrm{FDI} \\
\text { Openness }\end{array}$} \\
\hline & \multicolumn{2}{|c|}{ Encouraged } & \multicolumn{2}{|c|}{ Restricted } & \multicolumn{2}{|c|}{ Prohibited } & & \\
\hline & 1998 & 2002 & 1998 & 2002 & 1998 & 2002 & & \\
\hline 13 Food processing & 5 & 8 & 2 & 1 & 0 & 0 & 1.33 & High \\
\hline 14 Food manufacturing & 0 & 2 & 0 & 0 & 0 & 0 & 0.67 & High \\
\hline 15 Beverage manufacturing & 0 & 1 & 2 & 2 & 1 & 1 & 0.33 & \\
\hline 16 Tobacco processing & 0 & 0 & 1 & 1 & 0 & 0 & 0 & \\
\hline 17 Textiles & 1 & 1 & 2 & 2 & 0 & 0 & 0 & \\
\hline 18 Apparel & 0 & 1 & 0 & 0 & 0 & 0 & 0.33 & \\
\hline 19 Leather and fur products & 1 & 1 & 0 & 0 & 0 & 0 & 0 & \\
\hline 20 Wood products and processing & 0 & 1 & 3 & 2 & 0 & 0 & 0.67 & High \\
\hline 21 Furniture & 0 & 0 & 0 & 0 & 0 & 0 & 0 & \\
\hline 22 Paper and paper products & 1 & 2 & 1 & 0 & 1 & 1 & 0.67 & High \\
\hline $\begin{array}{l}23 \text { Printing and reproduction of } \\
\text { recorded media }\end{array}$ & 0 & 0 & 1 & 1 & 0 & 0 & 0 & \\
\hline $\begin{array}{l}24 \text { Cultural, educational, and } \\
\text { sporting goods }\end{array}$ & 0 & 0 & 0 & 0 & 0 & 0 & 0 & \\
\hline $\begin{array}{l}25 \text { Processing of petroleum, coking, } \\
\text { and nuclear fuel production }\end{array}$ & 1 & 1 & 1 & 1 & 0 & 0 & 0 & \\
\hline $\begin{array}{l}26 \text { Raw chemicals and chemical } \\
\text { products }\end{array}$ & 13 & 17 & 6 & 5 & 0 & 0 & 1.67 & High \\
\hline 27 Pharmaceuticals & 12 & 15 & 9 & 4 & 2 & 3 & 2.33 & High \\
\hline 28 Chemical fiber & 6 & 6 & 5 & 3 & 0 & 0 & 0.67 & High \\
\hline 29 Rubber products & 0 & 2 & 2 & 1 & 0 & 0 & 1 & High \\
\hline 30 Plastic products & 2 & 2 & 0 & 0 & 0 & 0 & 0 & \\
\hline 31 Non-metallic mineral products & 10 & 11 & 0 & 0 & 2 & 1 & 0.67 & High \\
\hline $\begin{array}{l}32 \text { Production and processing of } \\
\text { ferrous metals }\end{array}$ & 3 & 1 & 1 & 0 & 0 & 0 & -0.33 & \\
\hline $\begin{array}{l}33 \text { Production and processing of } \\
\text { non-ferrous metals }\end{array}$ & 3 & 5 & 1 & 1 & 0 & 0 & 0.67 & High \\
\hline 34 Metal products & 2 & 2 & 1 & 1 & 0 & 0 & 0 & \\
\hline 35 General purpose machinery & 6 & 7 & 5 & 2 & 0 & 0 & 1.33 & High \\
\hline 36 Special purpose machinery & 17 & 24 & 2 & 3 & 0 & 0 & 2 & High \\
\hline 37 Transportation equipment & 8 & 14 & 5 & 0 & 0 & 0 & 3.67 & High \\
\hline $\begin{array}{l}39 \text { Electrical machinery and } \\
\text { equipment }\end{array}$ & 0 & 0 & 0 & 0 & 1 & 1 & 0 & \\
\hline $\begin{array}{l}40 \text { Communication, computer, and } \\
\text { electronic equipment }\end{array}$ & 8 & 9 & 5 & 0 & 0 & 0 & 2 & High \\
\hline $\begin{array}{l}41 \text { Measuring, analyzing, and } \\
\text { controlling instruments }\end{array}$ & 12 & 13 & 5 & 0 & 1 & 1 & 2 & High \\
\hline 42 Miscellaneous manufacturing & 8 & 11 & 4 & 1 & 0 & 0 & 2 & High \\
\hline
\end{tabular}

Notes: The columns with the headings Encouraged, Restricted, and Prohibited count the number of economic activities in each two-digit industry classified in China's Catalogue for the Guidance of Investment Industries in its 1998 and 2002 revisions. Mean Change calculates the average change in the number of activities that were liberalized from one revision to another - either added to the list of Encouraged activities or removed from the list of Restricted or Prohibited activities. High $\Delta$ FDI Openness indicates an above-median industry with regard to its average change in the number of liberalized activities.

The last column of the table indicates which of the two-digit industries experienced a relatively strong degree of FDI liberalization based on a count of individual activities. 


\section{Appendix B. Joint Venture Firms in Comparison}

Success of the foreign investor in the Chinese market hinges on the strong performance of the JV firm. To ensure this, the foreign investor will transfer advanced technological knowledge to the JV as part of an optimal investment strategy. This technology transfer is central to any benefits that FDI might have to firms in the host country economy. In the following we comparing the performance of JVs with other firms in the host economy. The comparison set of firms here consists of all (non-JV-partner) domestic firms, excluding firms which are majority foreign-owned. Because JV firms are not observed prior to their formation, we are unable to systematically control for the underlying characteristics of these firms in the analysis that follows. Consequently, these results should be interpreted as simple comparisons; they do not shed light on the causal effect of JV status.

We estimate the following regression equation by OLS:

$$
y_{i t}=\alpha+\beta_{1} J V \text { Firm }_{i}+\beta_{2}\left[J V \text { Firm }_{i} \times W T O_{t}\right]+\boldsymbol{X}_{i t}^{\prime} \gamma+\eta_{j}+\nu_{r}+\mu_{t}+\varepsilon_{i j r t}
$$

where $y_{i t}$ is an outcome of firm $i$ in year $t$, and $J V$ Firm $_{i}$ is an indicator for whether the firm was established via an international JV. $\boldsymbol{X}_{i t}$ is a vector of firm characteristics, and $\eta_{j}, \nu_{r}$, and $\mu_{t}$ are industry, region, and year fixed effects, respectively. The coefficient $\beta_{1}$ gives the average difference in outcome $y$ between JVs and other firms in China conditional on industry, region, and time, as well as the characteristics in $\boldsymbol{X}_{i t}$, while coefficient $\beta_{2}$ captures how this difference has changed as China entered the WTO. In estimating equation (B.1) we also control for firm-level markups along the lines of De Loecker, Eeckhout, and Unger (2020). Table B1 shows the results.

From the results in column 1, it can be seen that, prior to 2002, JVs possessed a productivity advantage of more than $50 \%$ compared to other Chinese firms in the same region and industry. Moreover, JVs engage in higher levels of patenting and have a relatively higher share of new products in their total sales (columns 2 and 3). JVs' sales are about $56 \%$ higher, and they export more (columns 4 and 5). These results are consistent with substantial foreign technology transfer to the JVs. Furthermore, it is easy to see that, were this technological knowledge to be disseminated to other local firms as an external effect, it would have quantitatively significant effects on the local economy.

According to several performance measures, the premium of JV firms is reduced in the post-2002 period. This may be due to a number of reasons. One is that foreign investors transfer less technology to their JV in the WTO era, although it is not clear why this would be optimal. Another possibility is that these results reflect that, by 2002, Chinese firms had to some extent "caught up" with foreign investors compared to the pre-WTO period. However, it is important to 
qualify the results in Table B1 as they relate to our main findings on partner firms' performance: namely, JVs are only observed once they are established, i.e., JV Firmi cannot be separately identified from a firm fixed effect. Consequently, our results in this analysis to some extent reflect changes in the composition of the sample. In contrast, we find evidence for significantly higher rates of innovation by JVs, as measured by patenting, after China entered the WTO (column 3).

Table B1: JV Firms and Performance Differences

\begin{tabular}{|c|c|c|c|c|c|}
\hline & $\begin{array}{c}(1) \\
\text { TFP }\end{array}$ & $\begin{array}{c}\text { (2) } \\
\text { Patents }\end{array}$ & $\begin{array}{c}(3) \\
\text { New Prod. } \\
\text { Ratio }\end{array}$ & $\begin{array}{c}(4) \\
\text { Sales }\end{array}$ & $\begin{array}{c}(5) \\
\text { Export } \\
\text { Ratio }\end{array}$ \\
\hline JV Firm & $\begin{array}{c}0.494^{* *} \\
(0.045)\end{array}$ & $\begin{array}{c}0.052^{*} \\
(0.022)\end{array}$ & $\begin{array}{c}0.036^{* *} \\
(0.009)\end{array}$ & $\begin{array}{c}0.563^{* *} \\
(0.048)\end{array}$ & $\begin{array}{c}0.084^{* *} \\
(0.016)\end{array}$ \\
\hline JV Firm $\times$ WTO & $\begin{array}{c}-0.198^{* *} \\
(0.039)\end{array}$ & $\begin{array}{c}-0.036^{*} \\
(0.018)\end{array}$ & $\begin{array}{c}-0.031^{* *} \\
(0.008)\end{array}$ & $\begin{array}{c}-0.230^{* *} \\
(0.041)\end{array}$ & $\begin{array}{c}-0.006 \\
(0.013)\end{array}$ \\
\hline Employees & $\begin{array}{c}0.850^{* *} \\
(0.003)\end{array}$ & $\begin{array}{c}0.031^{* *} \\
(0.001)\end{array}$ & $\begin{array}{l}0.010^{* *} \\
(0.000)\end{array}$ & $\begin{array}{c}0.833^{* *} \\
(0.003)\end{array}$ & $\begin{array}{c}0.027^{* *} \\
(0.000)\end{array}$ \\
\hline Age & $\begin{array}{c}-0.240^{* *} \\
(0.003)\end{array}$ & $\begin{array}{c}-0.005^{* *} \\
(0.001)\end{array}$ & $\begin{array}{c}-0.002^{* *} \\
(0.000)\end{array}$ & $\begin{array}{c}-0.150^{* *} \\
(0.003)\end{array}$ & $\begin{array}{c}-0.009^{* *} \\
(0.001)\end{array}$ \\
\hline Foreign Share & $\begin{array}{c}0.327^{* *} \\
(0.024)\end{array}$ & $\begin{array}{c}0.031^{* *} \\
(0.010)\end{array}$ & $\begin{array}{c}0.007^{*} \\
(0.003)\end{array}$ & $\begin{array}{c}0.348^{* *} \\
(0.025)\end{array}$ & $\begin{array}{c}0.178^{* *} \\
(0.008)\end{array}$ \\
\hline Govt. Share & $\begin{array}{c}-0.776^{* *} \\
(0.009)\end{array}$ & $\begin{array}{c}-0.011^{* *} \\
(0.001)\end{array}$ & $\begin{array}{l}0.004^{* *} \\
(0.001)\end{array}$ & $\begin{array}{c}-0.856^{* *} \\
(0.009)\end{array}$ & $\begin{array}{c}-0.026^{* *} \\
(0.001)\end{array}$ \\
\hline Subsidy & $\begin{array}{c}0.195^{* *} \\
(0.005)\end{array}$ & $\begin{array}{c}0.032^{* *} \\
(0.002)\end{array}$ & $\begin{array}{c}0.013^{* *} \\
(0.001)\end{array}$ & $\begin{array}{c}0.209^{* *} \\
(0.005)\end{array}$ & $\begin{array}{c}0.004^{* *} \\
(0.001)\end{array}$ \\
\hline Markup & $\begin{array}{c}-0.045 \\
(0.037)\end{array}$ & $\begin{array}{c}0.002 \\
(0.002)\end{array}$ & $\begin{array}{c}0.001 \\
(0.001)\end{array}$ & $\begin{array}{c}-0.013 \\
(0.016)\end{array}$ & $\begin{array}{c}-0.002 \\
(0.001)\end{array}$ \\
\hline Observations & 773,078 & 665,921 & 793,613 & 793,603 & 793,613 \\
\hline
\end{tabular}

Notes: Dependent variables are given in each column heading. Estimation method is OLS. Estimation of equation (B.1). Estimation includes industry, province, and year fixed effects. Patents, Sales, Employees, and Age are expressed in natural logarithms. Estimation sample includes domestically owned Chinese firms and JV firms; JV partner firms and majority foreign-owned firms are excluded. Robust standard errors clustered at the firm level reported in parentheses. ${ }^{* *} p<0.01,{ }^{*} p<0.05,{ }^{+} p<0.1$. 